\title{
Magnetically Recyclable $\mathrm{Fe}_{3} \mathrm{O}_{4} / \mathrm{GO}-\mathrm{NH}_{2} / \mathrm{H}_{3} \mathrm{PMo}_{12} \mathrm{O}_{40}$ Nanocomposite: Synthesis, Characterization, and Application in Selective Adsorption of Cationic Dyes from Water
}

\author{
Saeed Farhadi, ${ }^{\star, 1}$ Mohammad Hakimi ${ }^{2}$ and Mansoureh Maleki ${ }^{2}$ \\ ${ }^{1}$ Chemistry Department, Lorestan University, Khoramabad 68151-44316, Iran. \\ ${ }^{2}$ Chemistry Department, Payame Noor University, Tehran 19395-4697, Iran. \\ * Corresponding author: E-mail: sfarhadi1348@yahoo.com \\ Tel.: +986633120611 fax: +986633120618
}

Received: 03-08-2017

\begin{abstract}
In this study, the $\mathrm{PMo}_{12} \mathrm{O}_{40}{ }^{3-}$ polyanion was immobilized chemically on amino functionalized magnetic graphene oxide nanosheets. The as-prepared ternary magnetic nanocomposite $\left(\mathrm{Fe}_{3} \mathrm{O}_{4} / \mathrm{GO}-\mathrm{NH}_{2} / \mathrm{H}_{3} \mathrm{PMo}_{12} \mathrm{O}_{40}\right)$ was characterized by powder X-ray powder diffraction (XRD), fourier transformation infrared spectroscopy (FTIR), Raman spectroscopy, energy dispersive spectroscopy (EDX), field emission scanning electron microscopy (FESEM), BET surface area measurements, magnetic measurements (VSM) and atomic force microscopy (AFM). The results demonstrated the successful loading of $\mathrm{H}_{3} \mathrm{PMo}_{12} \mathrm{O}_{40}(\sim 36.5 \mathrm{wt}$.\%) on the surface of magnetic graphene oxide. The nanocomposite showed a higher specific surface area $\left(77.07 \mathrm{~m}^{2} / \mathrm{g}\right)$ than pure $\mathrm{H}_{3} \mathrm{PMo}_{12} \mathrm{O}_{40}\left(\leq 10 \mathrm{~m}^{2} / \mathrm{g}\right)$. The adsorption efficiency of this nanocomposite for removing methylene blue $(\mathrm{MB})$, rhodamine $\mathrm{B}(\mathrm{RhB})$ and methyl orange $(\mathrm{MO})$ from aqueous solutions was evaluated. The nanocomposite showed rapid and selective adsorption for cationic dyes from mixed dye solutions. The adsorption rate and capacity of $\mathrm{Fe}_{3} \mathrm{O}_{4} / \mathrm{GO}-\mathrm{NH}_{2} / \mathrm{H}_{3} \mathrm{PMo}_{12} \mathrm{O}_{40}$ were enhanced as compared with GO, GO-NH, $\mathrm{Fe}_{3} \mathrm{O}_{4} / \mathrm{GO}_{-} \mathrm{NH}_{2}$, and $\mathrm{H}_{3} \mathrm{PMo}_{12} \mathrm{O}_{40}$ samples due to enhanced electrostatic attraction and hydrogen-bonding interactions. The nanocomposite is magnetically separated and reused without any change in structure. Thus, it could be a promising green adsorbent for removing organic pollutants in water.
\end{abstract}

Keywords: Graphene oxide nanosheets; Magnetic nanocomposite; Polyoxometalates; Organic dyes; Adsorption; $\mathrm{Fe}_{3} \mathrm{O}_{4}$ nanoparticles.

\section{Introduction}

Industrial activities release an increasing amount of contaminants, such as metal ions, organic dyes, and cleaning agents, which has raised public concern. ${ }^{1,2}$ So, wastewater treatment has attracted much attention in the past decades because of grievous effluent discharge of some organic dyes from plating, textile, and printing paper, plastic, cosmetic, pharmaceutical, and food industries that are resistant to biological degradation, making them quite difficult to remove from the wastewater. ${ }^{3,4}$ Organic dyes are not only highly visible and, even in a small amount, decrease gas solubility in water, but also toxic, carcinogenic, and mutagenic for human beings. ${ }^{5-9}$ Owing to their complex aromatic molecular structures, dyes are generally sta- ble to light, heat and oxidizing agents..$^{10}$ Therefore, effective removal of dyes from dye-wastewater is essential. Among the various technologies such as photocatalytic degradation, ${ }^{11}$ electrochemical degradation, ${ }^{12}$ and adsorption, ${ }^{13}$ adsorption is considered one of the most efficient and economical methods for water purification. ${ }^{14}$ Many polymeric and inorganic adsorbents such as carbonaceous nanomaterials ${ }_{15}^{15}$ porous metal oxides, ${ }^{16}$ clays,${ }^{17}$ chitosan, ${ }^{18}$ zeolites, ${ }^{19}$ and so on ${ }^{20,21}$ were developed for removing pollutants from aqueous solutions. However, such adsorbents are associated with certain problems that limit their practical applications, such as low adsorption capacity, slow adsorption rate, and difficult separation of the adsorbents. ${ }^{22}$ Furthermore, some of them are only effective for wastewater including low concentrations of dyes and they 
are generally poor at selectively removing the targeted organic dye wastes. Hence, in this regard, it is extremely imperative to find a new desirable adsorption material, which not only is capable of reducing the organic dyes in dye-wastewater with high efficiency and fast adsorption rate but also can achieve selective separation and recovery of raw materials.

Polyoxometalates (POMs), as an outstanding class of anionic metal oxide clusters, have attracted great attention due to their earth-abundant source, rich topology and versatility, controllable shape and size, oxo-enriched surfaces, high electronegativity etc. ${ }^{23}$ which have various applications in many fields, such as catalysis, ${ }^{24}$ optics, ${ }^{25}$ magnetism, ${ }^{26}$ biological medicine, ${ }^{27}$ and dye adsorption. ${ }^{28}$ The strong attraction of POMs to cationic dyes suggests that they are potential and suitable adsorbents for selectively capturing cationic dyes. However, there are still obvious disadvantages for POMs as adsorbents: (i) their relatively small surface area seriously obstructs the accessibility to the active sites and (ii) their excellent solubility in aqueous solution determines that they cannot be reused and recycled in the process of wastewater treatment. Therefore, plenty of remarkable work has been done to encapsulate POMs into porous solid matrices, such as activated carbon $^{29}$ and silica ${ }^{30}$ for creating composite materials. Unfortunately, these methods sometimes lead to low POM loading; it is thus of vital significance to search for an applicable solid matrix to immobilize POMs, which might greatly improve their adsorption ability for target dyes.

Among various materials, graphene oxide (GO) has been proven as an effective sorbent for the removal of inorganic and organic pollutants owing to its large theoretical specific surface area $\left(\sim 2630 \mathrm{~m}^{2} / \mathrm{g}\right)$ and the presence of several active sites on its surface. ${ }^{31-39}$ In addition, in comparison with other carbonaceous nanomaterials, GO may be more environmental friendly and have better biocompatibility. ${ }^{40}$ However, it is difficult to separate it from aqueous solution because of its small particle size, causing serious health and environmental problems once it is discharged into the environment. ${ }^{41}$ The centrifugation method needs a very high rate and the traditional filtration method may cause blockages of filters. Compared with traditional centrifugation and filtration methods, the magnetic separation method is considered as a rapid and effective technique for separating nanomaterials from aqueous solution. ${ }^{42,43}$ Hence, magnetite/graphene composites with large specific surface area (enhancing the removal of water pollutants) and magnetic separation (facilitated by the recycling of the composites) have begun to be used in the field of environmental treatment. ${ }^{4-48}$

On the basis of the above discussion, in this work, amino functionalized magnetic graphene oxide $\left(\mathrm{Fe}_{3} \mathrm{O}_{4} /\right.$ GO- $\mathrm{NH}_{2}$ ) was synthesized by a facile method and used as a novel support for immobilizing Keggin-type $\mathrm{PMo}_{12} \mathrm{O}_{40}{ }^{3-}$ anions. This magnetically recoverable ternary nanocomposite material $\left(\mathrm{Fe}_{3} \mathrm{O}_{4} / \mathrm{GO}-\mathrm{NH}_{2} / \mathrm{H}_{3} \mathrm{PMo}_{12} \mathrm{O}_{40}\right)$ was pre- pared by a simple acid-base electrostatic interaction between $\mathrm{H}_{3} \mathrm{PMo}_{12} \mathrm{O}_{40}$ and amino groups of $\mathrm{Fe}_{3} \mathrm{O}_{4} / \mathrm{GO}-\mathrm{NH}_{2}$. For one thing, $\mathrm{PMo}_{12} \mathrm{O}_{40}{ }^{3-}$ anion with highly electronegative and hydrophilic properties and structural stability could be utilized as a potential adsorbent for removal of the cationic dyes in dye-wastewater. For another, magnetic GO possesses outstanding porosity and extremely large surface area, and it is insoluble in water, which is an appropriate solid matrix to anchor Keggin-type $\mathrm{PMo}_{12} \mathrm{O}_{40}{ }^{3-}$ anions. The combination of polyoxoanions and $\mathrm{Fe}_{3} \mathrm{O}_{4} /$ GO- $-\mathrm{NH}_{2}$ could improve the surface area and avoid the dissolution of POM. The hybrid nanomaterial exhibited superior adsorption rate and selective adsorption ability for the cationic dyes. Remarkably, this material exhibited a largescale adsorption capacity of $426.7 \mathrm{mg} / \mathrm{g}$ for MB. Hence, it is a promising and environmental friendly adsorbent for removing and separating organic pollutants in dye-wastewater.

\section{Experimental}

\section{1. Materials and Characterization Techniques}

Graphite powder (C, 99.95\%), 3-aminopropyltriethoxysilane (APTES, 99\%), phosphomolybdic acid ( $\mathrm{H}_{3} \mathrm{P}-$ $\left.\mathrm{Mo}_{12} \mathrm{O}_{40}, 98 \%\right)$, toluene, sulfuric acid $\left(\mathrm{H}_{2} \mathrm{SO}_{4}, 98 \%\right)$, and potassium permanganate $\left(\mathrm{KMnO}_{4}, 98 \%\right)$ were purchased from Merck Chemical Co. All other chemicals were commercially purchased and used without further purification. The infrared spectra were recorded at room temperature using a Shimadzu FT-IR 160 spectrophotometer in the $4000-400 \mathrm{~cm}^{-1}$ region with $\mathrm{KBr}$ pellets. Powder XRD patterns were recorded on a Rigaku D-max C III X-ray diffractometer using Ni-filtered $\mathrm{Cu} \mathrm{Ka}$ radiation $(\lambda=1.54184 \AA)$. The morphology of samples was studied using a MIRA3 TESCAN scanning electron microscope equipped with an energy dispersive X-ray analyzer (EDX) for the elemental analysis. AFM images were recorded by multi-mode atomic force microscopy (ARA-AFM, model Full Plus, ARA Research Co., Iran). Magnetic measurements were carried out at room temperature using a vibrating sample magnetometer (VSM, Magnetic Daneshpajoh Kashan Co., Iran) with a maximum magnetic field of $10 \mathrm{kOe}$. Optical adsorption spectra were obtained using a Cary 100 Varian UV-Vis spectrophotometer in a wavelength range of 200$800 \mathrm{~nm}$. The Brunauer-Emmett-Teller (BET) surface area was measured by $\mathrm{N}_{2}$ adsorption measurements at $77 \mathrm{~K}$ using a Nova 2000 instrument. The concentration of Mo in the composite was determined by inductively coupled plasma atomic emission spectroscopy (ICP-AES, model OEC-730). A controllable Serial-Ultrasonics apparatus (James 6MD, England) operating at an ultrasonic frequency of $100 \mathrm{kHz}$ with a nominal output power of $50 \mathrm{~W}$ was used to disperse samples. 


\section{2. Preparation of Graphene Oxide}

Graphene oxide (GO) was prepared by the modified Hummers method through the oxidation of graphite powder. ${ }^{49,50}$ Graphite powder (2.0 g) and $\mathrm{NaNO}_{3}(1.0 \mathrm{~g})$ were mixed with $40 \mathrm{~mL}$ of concentrated $\mathrm{H}_{2} \mathrm{SO}_{4}$ in a $500 \mathrm{~mL}$ flask and stirred for $1 \mathrm{~h}$ in an ice bath. Then $\mathrm{KMnO}_{4}(6.0 \mathrm{~g})$ was added into the vigorously stirred suspension slowly below $15^{\circ} \mathrm{C}$. The ice bath was then removed, and the mixture was stirred at room temperature until it slowly became brownish slurry. It was diluted with $100 \mathrm{~mL}$ of water. The reaction temperature was rapidly increased to $98^{\circ} \mathrm{C}$ with effervescence, and the color changed to brown. After that, 200 $\mathrm{mL}$ of water and $20 \mathrm{~mL}$ of $\mathrm{H}_{2} \mathrm{O}_{2}(30 \mathrm{wt} . \%)$ were added. For purification, the mixture was centrifuged and washed with $10 \% \mathrm{HCl}$ and then deionized water several times to remove the residual metal ions and acid. After centrifuging and drying at room temperature, GO was obtained as a powder.

\section{3. Preparation of Magnetic Graphene Oxide $\left(\mathrm{Fe}_{3} \mathrm{O}_{4} / \mathrm{GO}\right)$}

$0.25 \mathrm{~g}$ of $\mathrm{GO}$ was dispersed in $90 \mathrm{~mL}$ of water by sonication for $1 \mathrm{~h}$. Then, $0.84 \mathrm{~g}$ of $\left(\mathrm{NH}_{4}\right)_{2} \mathrm{Fe}\left(\mathrm{SO}_{4}\right)_{2}$ and $2.08 \mathrm{~g}$ of $\left(\mathrm{NH}_{4}\right) \mathrm{Fe}\left(\mathrm{SO}_{4}\right)_{2}$ were added to the $\mathrm{GO}$ dispersion and its $\mathrm{pH}$ was adjusted at 12 by adding $1 \mathrm{~mol} / \mathrm{L} \mathrm{NaOH}$. The mixture was stirred at $50{ }^{\circ} \mathrm{C}$ for $2 \mathrm{~h}$, filtered and washed with water and ethanol three times. The resulting solid was $\mathrm{Fe}_{3} \mathrm{O}_{4} / \mathrm{GO}$.

\section{4. Preparation of Aminopropyl Functionalized Magnetic Graphene Oxide $\left(\mathrm{Fe}_{3} \mathrm{O}_{4} / \mathrm{GO}-\mathrm{NH}_{2}\right)$}

To a round bottom flask, $0.40 \mathrm{~g}$ of the as-synthesized $\mathrm{Fe}_{3} \mathrm{O}_{4} / \mathrm{GO}$ dispersed in $50 \mathrm{~mL}$ of water, $5 \mathrm{~mL}$ of APTES, and $150 \mathrm{~mL}$ of ethanol were added. The mixture was stirred for $30 \mathrm{~min}$ at room temperature and refluxed at $80^{\circ} \mathrm{C}$ for 24 h. After the reaction, the solid was separated by a magnet and washed with ethanol to remove the unreacted APTES. The final product was dried at $80^{\circ} \mathrm{C}$ in vacuum for $12 \mathrm{~h}$ to obtain $\mathrm{Fe}_{3} \mathrm{O}_{4} / \mathrm{GO}-\mathrm{NH}_{2}$.

\section{5. Preparation of the $\mathrm{Fe}_{3} \mathrm{O}_{4} / \mathrm{GO}-\mathrm{NH}_{2} /$ $\mathrm{H}_{3} \mathrm{PMo}_{12} \mathrm{O}_{40}$ Hybrid Nanomaterial}

$1 \mathrm{~g}$ of the as-prepared $\mathrm{Fe}_{3} \mathrm{O}_{4} / \mathrm{GO}-\mathrm{NH}_{2}$ was dispersed in $80 \mathrm{~mL}$ of water and sonicated for $1 \mathrm{~h}$. Then, $1 \mathrm{~g}$ of $\mathrm{H}_{3} \mathrm{P}$ $\mathrm{Mo}_{12} \mathrm{O}_{40}$ in $200 \mathrm{~mL}$ of ethanol was added and sonicated for another $1 \mathrm{~h}$. The resulting mixture was stirred at room temperature for $24 \mathrm{~h}$, filtered, and washed with deionized water and ethanol three times to remove the unreacted $\mathrm{H}_{3} \mathrm{PMo}_{12} \mathrm{O}_{40}$. The final product was dried at $60{ }^{\circ} \mathrm{C}$ in open air to obtain magnetic $\mathrm{Fe}_{3} \mathrm{O}_{4} \mathrm{GO}-\mathrm{NH}_{2} / \mathrm{H}_{3} \mathrm{PMo}_{12} \mathrm{O}_{40}$ hybrid nanomaterial. Elemental analysis (ICP-AES) showed that the Mo content in $\mathrm{Fe}_{3} \mathrm{O}_{4} / \mathrm{GO}-\mathrm{NH}_{2} / \mathrm{H}_{3} \mathrm{PMo}_{12} \mathrm{O}_{40}$ was
$32.55 \%$. According to the elemental analysis results and molecular weight of $\mathrm{H}_{3} \mathrm{PMo}_{12} \mathrm{O}_{40}$, the loading amount (wt.\%) of $\mathrm{H}_{3} \mathrm{PMo}_{12} \mathrm{O}_{40}$ in $\mathrm{Fe}_{3} \mathrm{O}_{4} / \mathrm{GO}-\mathrm{NH}_{2} / \mathrm{H}_{3} \mathrm{PMo}_{12} \mathrm{O}_{40}$ was estimated to be $36.5 \%$.

\section{6. Dye Adsorption Tests}

The aqueous stock solutions of dyes $(500 \mathrm{mg} / \mathrm{L})$ were prepared by dissolving solid dyes $(\mathrm{MB}, \mathrm{RhB}$, and $\mathrm{MO})$ in deionized water. Working solutions of dyes, when required, were prepared by successive dilution of the stock solution with deionized water. The adsorption experiments of dyes were performed in a $100 \mathrm{~mL}$ glass beaker and the adsorption reaction temperature was maintained at $25^{\circ} \mathrm{C}$. In a typical experiment, $25 \mathrm{mg}$ of the as-prepared $\mathrm{Fe}_{3} \mathrm{O}_{4} / \mathrm{GO}-\mathrm{NH}_{2} / \mathrm{H}_{3} \mathrm{PMo}_{12} \mathrm{O}_{40}$ hybrid nanomaterial was added into $50 \mathrm{~mL}$ of dye aqueous solution $\left(\mathrm{C}_{0}=25 \mathrm{mg} / \mathrm{L}\right)$ and stirred in the dark and at predetermined time intervals, a small portion $(3 \mathrm{~mL})$ of the dye solution was pipetted out and the solid adsorbent was separated by an external magnet. The concentration $\left(C_{t}\right)$ of the dye in the clear solution was determined by measuring the absorbance of the solution at fixed wavelengths, $664 \mathrm{~nm}$ for MB, $554 \mathrm{~nm}$ for $\mathrm{RhB}$, and $463 \mathrm{~nm}$ for $\mathrm{MO}$, using a UV-Vis spectrophotometer. A similar experiment was also performed with 50 $\mathrm{mL}$ of different concentrations of MB solutions $(5,15,25$, 35 , and $50 \mathrm{mg} / \mathrm{L}$ ). Also, the hybrid nanomaterial was transferred into the mixtures of $\mathrm{MB} / \mathrm{MO}$ (v:v 1/1, $50 \mathrm{~mL}$, $25 \mathrm{mg} / \mathrm{L}$ ), $\mathrm{MO} / \mathrm{RhB}$, and $\mathrm{MB} / \mathrm{MO} / \mathrm{RhB}$. UV-Vis spectroscopy was performed to determine the selective adsorption ability of hybrid nanomaterial at given time intervals. Furthermore, the adsorption capability of the $\mathrm{Fe}_{3} \mathrm{O}_{4}, \mathrm{Fe}_{3} \mathrm{O}_{4} /$ GO, $\mathrm{Fe}_{3} \mathrm{O}_{4} / \mathrm{GO}-\mathrm{NH}_{2}$, and $\mathrm{H}_{3} \mathrm{PMo}_{12} \mathrm{O}_{40}$ samples toward $\mathrm{MB}$ dye solution was evaluated under similar conditions as described above. $25 \mathrm{mg}$ of the as-prepared adsorbent was added into $50 \mathrm{~mL}$ of $25 \mathrm{mg} / \mathrm{L} \mathrm{MB}$ solution and stirred in the dark. Dye removal ability (\%) was calculated by measuring the dye absorbance at $664 \mathrm{~nm}$ before and after adsorption process at room temperature. Finally, $\mathrm{Fe}_{3} \mathrm{O}_{4} / \mathrm{GO}-$ $\mathrm{NH}_{2} / \mathrm{H}_{3} \mathrm{PMo}_{12} \mathrm{O}_{40}$ was investigated for its recycling property for the removal of $\mathrm{MB}$ after $\mathrm{Fe}_{3} \mathrm{O}_{4} / \mathrm{GO}-\mathrm{NH}_{2} / \mathrm{H}_{3} \mathrm{PMo}_{12} \mathrm{O}_{40}$ was separated, washed with ethanol, and dried in a vacuum oven. In all experiments, the adsorption efficiency $(\eta \%)$ and adsorption capacity $\left(\mathrm{q}_{\mathrm{r}} ; \mathrm{mg} / \mathrm{g}\right)$ were calculated according to the following equations:

$$
\begin{aligned}
& \eta \%=\left[\left(C_{0}-C_{t}\right) / C_{0}\right] \times 100=\left[\left(A_{0}-A_{t}\right) / A_{0}\right] \times 100 \\
& q_{t}=\left[\left(C_{0}-C_{t}\right) \times V\right] / m
\end{aligned}
$$

Where $\mathrm{C}_{0}(\mathrm{mg} / \mathrm{L})$ and $\mathrm{A}_{0}$ are the initial dye concentration and absorbance before removal at initial time $t=0$, $\mathrm{C}_{\mathrm{t}}(\mathrm{mg} / \mathrm{L})$ and $\mathrm{A}_{\mathrm{t}}$ are the concentration and absorbance of dye remaining in the solution after treatment with adsorbent at time $t, q_{t}$ is the amount of adsorbed MB molecules on the adsorbent (in $\mathrm{mg} / \mathrm{g}$ ). $\mathrm{V}$ (in $\mathrm{L}$ ) is the initial volume of the MB solution and $\mathrm{m}$ (in $\mathrm{g}$ ) is the mass of the adsorbent. 


\section{Results and Discussion}

\section{1. Characterization of the $\mathrm{Fe}_{3} \mathrm{O}_{4} / \mathrm{GO}-\mathrm{NH}_{2} /$ $\mathrm{H}_{3} \mathbf{P M o}_{12} \mathrm{O}_{40}$ Hybrid Nanomaterial}

The GO is an inexpensive, stable, environmentally benign, easily available solid material, and contains rich oxidation functional groups, such as hydroxyl, epoxide, carboxyl, and carbonyl groups. Due to these functional groups, GO can well disperse in polar solvents and forms a homogenous colloidal suspension, which facilitates the contact between reactant and catalytic active site. ${ }^{51}$ On the other hand, these rich functional groups can be easily reacted with organic molecules to generate stable covalent functional GO. ${ }^{19-21}$ These suggest that attaching organic bases on GO might afford an efficient, reusable and environmentally benign base support for heteropolyacids such as $\mathrm{PMo}_{12}$. In this work, Keggin-type $\mathrm{H}_{3} \mathrm{PMo}_{12} \mathrm{O}_{40}$ was immobilized onto 3-aminopropyl functionalized $\mathrm{GO}$ nanosheets decorated with magnetic $\mathrm{Fe}_{3} \mathrm{O}_{4}$ nanoparticles. The preparation of the $\mathrm{Fe}_{3} \mathrm{O}_{4} / \mathrm{GO}-\mathrm{NH}_{2} / \mathrm{H}_{3} \mathrm{PMo}_{12} \mathrm{O}_{40}$ hybrid is illustrated in Figure 1. The surface of GO-NH ly charged by the protonation of $-\mathrm{NH}_{2}$, which helps in anchoring the $\mathrm{PMo}_{12} \mathrm{O}_{40}{ }^{3-}$ anion due to electrostatic attraction. To confirm the successful construction of the $\mathrm{Fe}_{3} \mathrm{O}_{4} /$ GO- $\mathrm{NH}_{2} / \mathrm{H}_{3} \mathrm{PMo}_{12} \mathrm{O}_{40}$ hybrid, elemental analysis was employed. It revealed that $\mathrm{Fe}_{3} \mathrm{O}_{4} / \mathrm{GO}-\mathrm{NH}_{2} / \mathrm{H}_{3} \mathrm{PMo}_{12} \mathrm{O}_{40}$ contains $36.5 \% \mathrm{Mo}$, indicating that $\mathrm{H}_{3} \mathrm{PMo}_{12} \mathrm{O}_{40}$ molecules were anchored on GO nanosheets. Due to the electrostatic attraction of the absorbed $\mathrm{PMo}_{12} \mathrm{O}_{40}{ }^{3-}$ and $-\mathrm{NH}_{3}{ }^{+}$group, the hydrogen bonds between $-\mathrm{NH}_{3}{ }^{+}$and $\mathrm{H}_{3} \mathrm{PMo}_{12} \mathrm{O}_{40}$ molecules are reinforced. ${ }^{52-54}$ These are the possible reasons for the significant enhancement of $\mathrm{Fe}_{3} \mathrm{O}_{4} / \mathrm{GO}-\mathrm{NH}_{2} / \mathrm{H}_{3} \mathrm{P}-$ $\mathrm{Mo}_{12} \mathrm{O}_{40}$ adsorptivity. Moreover, the structure and composition of the hybrid nanomaterial was characterized by XRD, FT-IR, Raman spectra, EDX, SEM, AFM, VSM, and BET surface area analyses.

Figure 2 displays the XRD patterns for $\mathrm{Fe}_{3} \mathrm{O}_{4}, \mathrm{Fe}_{3} \mathrm{O}_{4} /$ $\mathrm{GO}-\mathrm{NH}_{2}$, and $\mathrm{Fe}_{3} \mathrm{O}_{4} / \mathrm{GO}-\mathrm{NH}_{2} / \mathrm{H}_{3} \mathrm{PMo}_{12} \mathrm{O}_{40}$ samples. All the diffraction patterns in Figure 2(a)-(c) are similar and can be indexed to the $\mathrm{Fe}_{3} \mathrm{O}_{4}$ phase (JCPDS No. 41-1488). No characteristic diffraction peaks of the $\mathrm{H}_{3} \mathrm{PMo}_{12} \mathrm{O}_{40}$ appeared which presumably was due to the low content incorporation of $\mathrm{H}_{3} \mathrm{PMo}_{12} \mathrm{O}_{40}$. Also this result implies that the Keggin unit homogeneously disperses into the GO

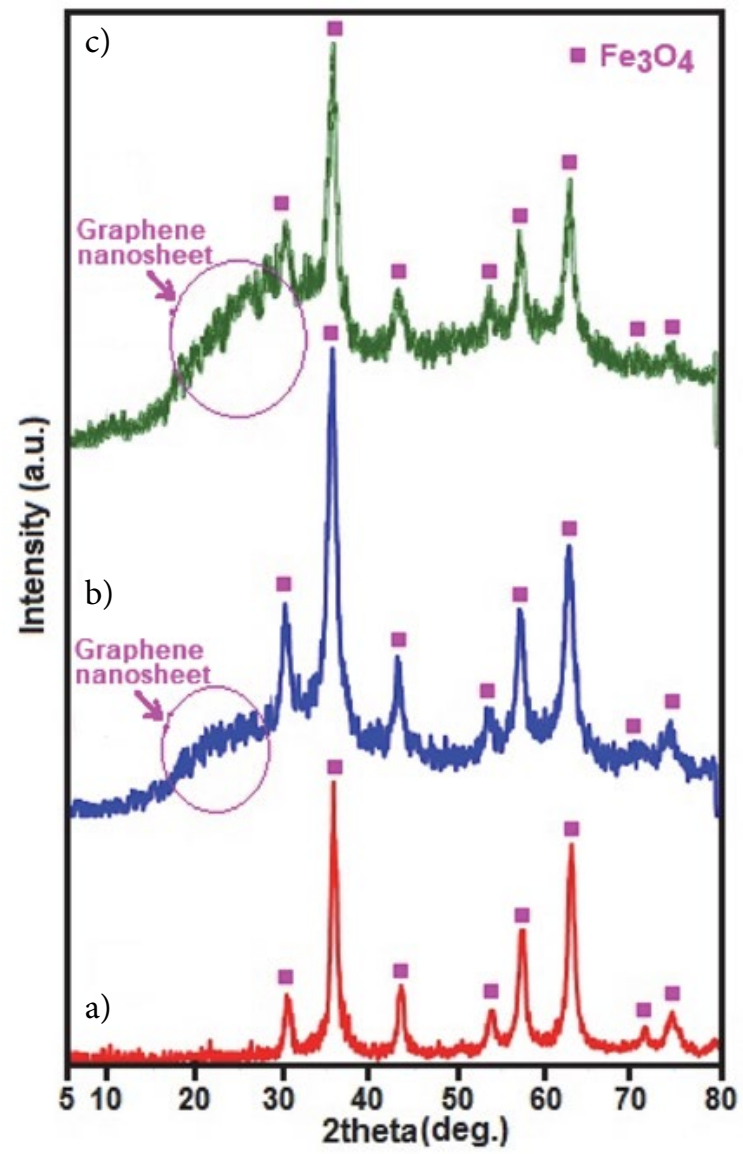

Figure 2. XRD patterns of (a) pure $\mathrm{Fe}_{3} \mathrm{O}_{4}$, (b) $\mathrm{Fe}_{3} \mathrm{O}_{4} / \mathrm{GO}-\mathrm{NH}_{2}$ and (c) $\mathrm{Fe}_{3} \mathrm{O}_{4} / \mathrm{GO}-\mathrm{NH}_{2} / \mathrm{H}_{3} \mathrm{PMo}_{12} \mathrm{O}_{40}$
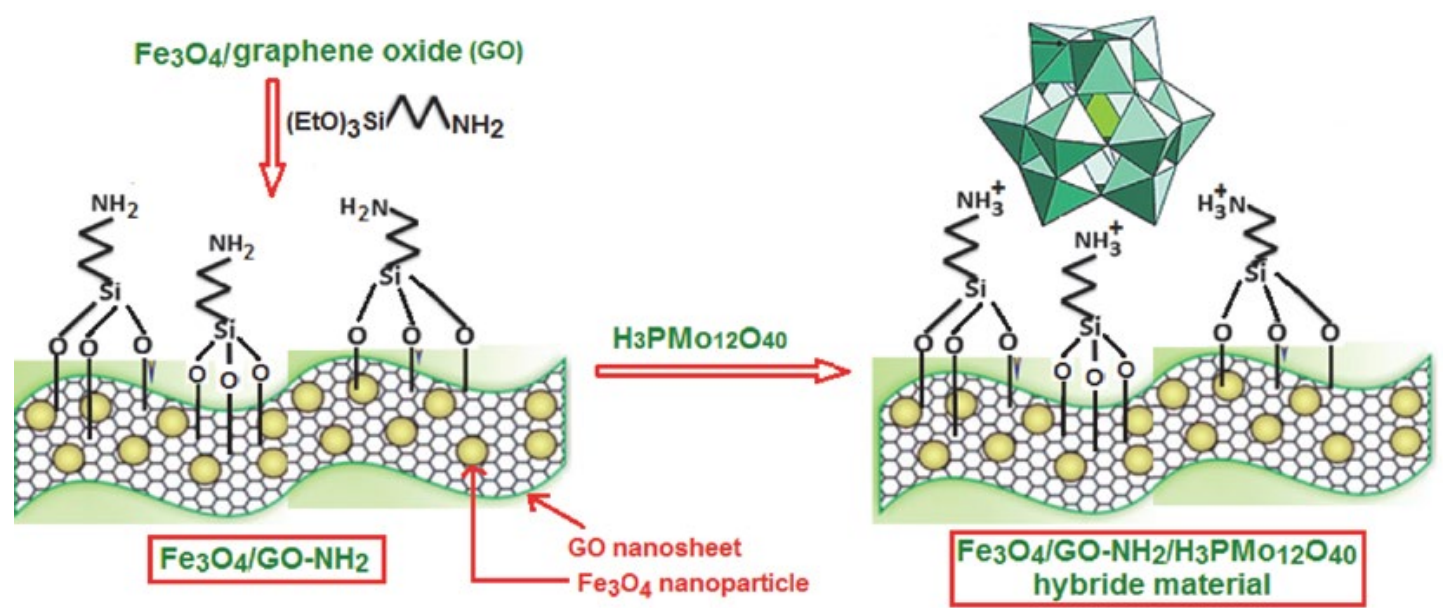

Figure 1. The preparation procedure to attach $\mathrm{H}_{3} \mathrm{PMo}_{12} \mathrm{O}_{40}$ on the surface of aminopropyl functionalized magnetic graphene oxide.

Farhadi et al.: Magnetically Recyclable $\mathrm{Fe}_{3} \mathrm{O}_{4} / \mathrm{GO}-\mathrm{NH}_{2} / \mathrm{H}_{3} \mathrm{PMo} \mathrm{I}_{12} \mathrm{O}_{40} \quad \cdots$ 
nanosheets, which will help to enhance the adsorption activity of the hybrid nanomaterial. Moreover, no characteristic diffraction peaks for $\mathrm{GO}$ are observed in the pattern indicating that the GO nanosheets do not stack during the synthesis. The reason can be attributed to the $\mathrm{Fe}_{3} \mathrm{O}_{4}$ and $\mathrm{H}_{3} \mathrm{PMo}_{12} \mathrm{O}_{40}$ nanoparticles anchored on the surfaces of GO to prevent the exfoliated GO nanosheets from restacking. ${ }^{55}$ However, a broad characteristic peak for graphene nanosheets at about $2 \boldsymbol{\theta}=23$ appeared, suggesting that the $\mathrm{GO}$ was reduced to graphene during the functionalization process.

The FT-IR spectra of synthesized materials are shown in Figure 3. The FT-IR spectrum of the GO in Figure 3(a) shows the $\mathrm{C}=\mathrm{O}$ and graphitic $\mathrm{C}=\mathrm{C}$ stretching bands at about 1735 and $1626 \mathrm{~cm}^{-1}$, respectively. ${ }^{56}$ Also, the strong band at $1030 \mathrm{~cm}^{-1}$ is related to the stretching vibrations of the $\mathrm{C}-\mathrm{OH}$ bonds. In the spectrum of $\mathrm{Fe}_{3} \mathrm{O}_{4} /$ GO-Si $\left(\mathrm{CH}_{2}\right)_{3} \mathrm{NH}_{2}$ sample (abbreviated as $\mathrm{Fe}_{3} \mathrm{O}_{4} / \mathrm{GO}-\mathrm{NH}_{2}$ ) in Figure 3(b), the strong band at about $588 \mathrm{~cm}^{-1}$ is assigned to the $\mathrm{Fe}-\mathrm{O}$ stretching vibration of the spinel-type $\mathrm{Fe}_{3} \mathrm{O}_{4}$ structure. ${ }^{57}$ The presence of $\mathrm{Si}-\mathrm{O}$ bond was confirmed by a strong band at about $1116 \mathrm{~cm}^{-1}$ assigned to the $\mathrm{Si}-\mathrm{O}-\mathrm{C}$ stretching vibration. ${ }^{58,59}$ Also, two broad bands at 3430 and $1630 \mathrm{~cm}^{-1}$ can be ascribed to the stretching and bending modes of $-\mathrm{NH}_{2}$ groups, respectively. The presence of the anchored propyl chain of APTES was confirmed by $\mathrm{C}-\mathrm{H}$ stretching vibrations at 2926 and 2850 $\mathrm{cm}^{-1} .{ }^{59}$ The FT-IR spectrum of the $\mathrm{Fe}_{3} \mathrm{O}_{4} / \mathrm{GO}-\mathrm{NH}_{2}$ exhibits peaks at 1223 and $1028 \mathrm{~cm}^{-1}$ corresponding to $\mathrm{C}-\mathrm{N}$ and $\mathrm{C}-\mathrm{OH}$, respectively. ${ }^{60}$ These show the successful grafting of APTES onto the magnetic GO sheet through covalent bonds. It is well known that Keggin-type $\mathrm{PMo}_{12} \mathrm{O}_{40}{ }^{3-}$ polyoxometalate contains a cluster of $\mathrm{Mo}(\mathrm{VI})$ ions linked by oxygen atoms with a tetrahedral phosphate group. Oxygen atoms form four physically distinct bonds $\left(\mathrm{P}-\mathrm{O}_{\mathrm{a}}, \mathrm{Mo}-\mathrm{O}_{\mathrm{t}}\right.$, $\mathrm{Mo}-\mathrm{O}_{\mathrm{b}}-\mathrm{Mo}$, and $\mathrm{Mo}-\mathrm{O}_{\mathrm{c}}-\mathrm{Mo}$ bonds), which have distinct infrared signatures as shown in Figure 3(c): $1066 \mathrm{~cm}^{-1}$ for asymmetric stretch vibration of $\mathrm{P}-\mathrm{O}_{\mathrm{a}}\left(\mathrm{O}_{\mathrm{a}}\right.$ corresponds to oxygen atom of tetrahedral phosphate group), $966 \mathrm{~cm}^{-1}$ for asymmetric stretch vibration of $\mathrm{Mo}=\mathrm{O}_{\mathrm{t}}\left(\mathrm{O}_{\mathrm{t}}\right.$ corresponds to the terminal oxygen atoms), $870 \mathrm{~cm}^{-1}$ for bending vibration of $\mathrm{Mo}-\mathrm{O}_{\mathrm{b}}-\mathrm{Mo}\left(\mathrm{O}_{\mathrm{b}}\right.$ corresponds to oxygen atom bridging the two tungsten atoms), and $786 \mathrm{~cm}^{-1}$ for bending vibration of $\mathrm{Mo}-\mathrm{O}_{c}-\mathrm{Mo}\left(\mathrm{O}_{c}\right.$ represents oxygen atom at the corners of the Keggin structure).$^{61}$ The FT-IR spectrum of the hybrid nanomaterial sample is shown in Figure 3(d), the absorption peaks of $\mathrm{PMo}_{12} \mathrm{O}_{40}{ }^{3-}$ cluster at 1053, 945, 875 , and $798 \mathrm{~cm}^{-1}$ corresponding to the $\mathrm{P}-\mathrm{O}_{\mathrm{a}}, \mathrm{Mo}=\mathrm{O}_{\mathrm{t}}$, $\mathrm{Mo}-\mathrm{O}_{\mathrm{b}}-\mathrm{Mo}$ and $\mathrm{Mo}-\mathrm{O}_{\mathrm{c}}-\mathrm{Mo}$ band vibrations, and the vibrational bands of $\mathrm{Fe}_{3} \mathrm{O}_{4} / \mathrm{GO}-\mathrm{NH}_{2}$ located around 1605, $1383,1042,746$, and $543 \mathrm{~cm}^{-1}$ were all observed in the IR spectrum of the hybrid nanomaterial which demonstrates the coexistence of $\mathrm{PMo}_{12} \mathrm{O}_{40}{ }^{3-}, \mathrm{Fe}_{3} \mathrm{O}_{4}$, and $\mathrm{GO}-\mathrm{NH}_{2}$ in the hybrid nanomaterial. The red/blue shift of peaks of the $\mathrm{Fe}_{3} \mathrm{O}_{4} / \mathrm{GO}-\mathrm{NH}_{2} / \mathrm{H}_{3} \mathrm{PMo}_{12} \mathrm{O}_{40}$ compared with the parent $\mathrm{H}_{3} \mathrm{PMo}_{12} \mathrm{O}_{40}$ can be attributed to strong attraction between negatively charged $\mathrm{PMo}_{12} \mathrm{O}_{40}{ }^{3-}$ and positively charged $\mathrm{Fe}_{3} \mathrm{O}_{4} / \mathrm{GO}-\mathrm{NH}_{3}{ }^{+}$surface. ${ }^{62,63}$ Raman spectroscopy is a powerful tool to characterize the significant structural changes in GO during the $\mathrm{Fe}_{3} \mathrm{O}_{4} / \mathrm{GO}-\mathrm{NH}_{2} / \mathrm{H}_{3} \mathrm{PMo}_{12} \mathrm{O}_{40}$ hybrid synthesis.

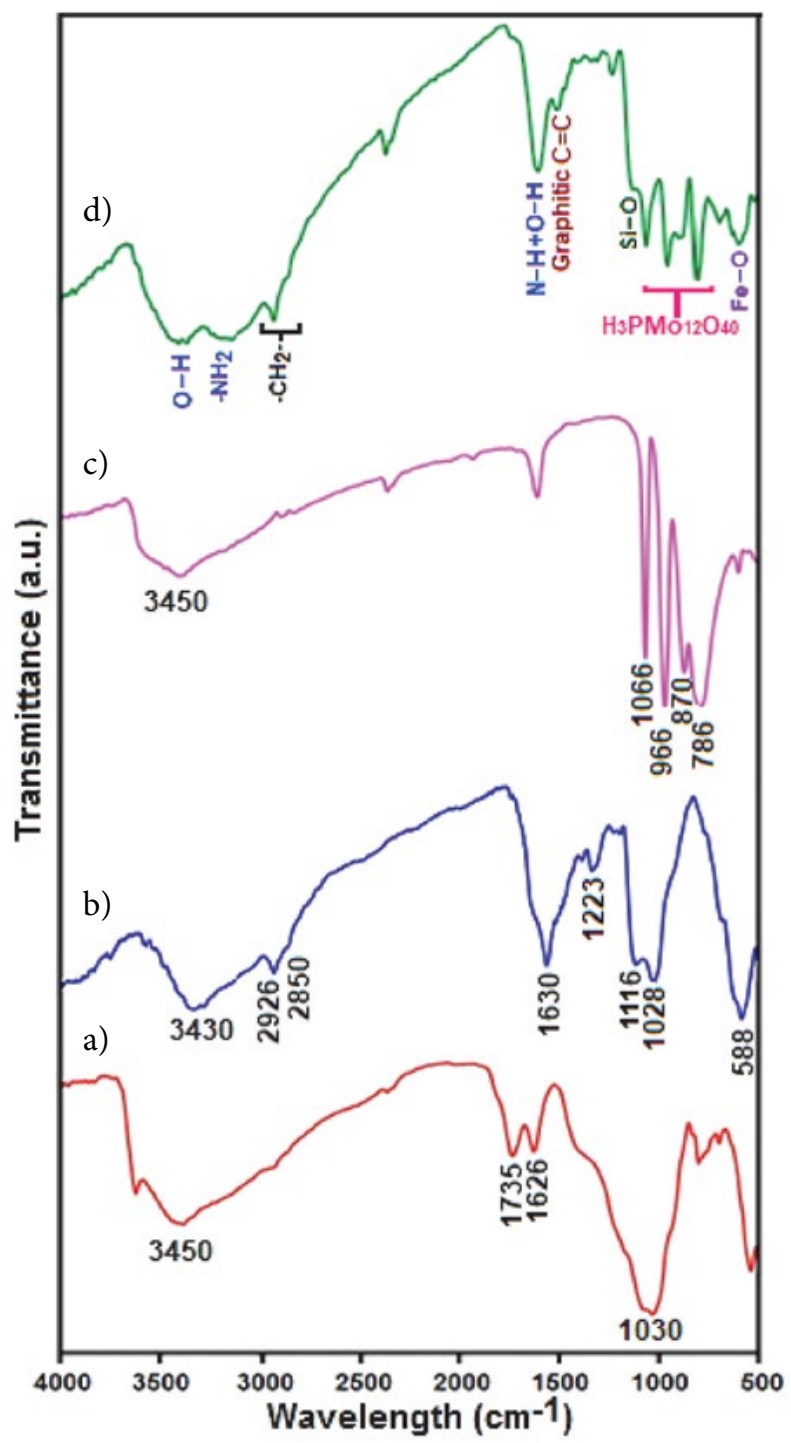

Figure 3. IR spectra of (a) pure GO, (b) $\mathrm{Fe}_{3} \mathrm{O}_{4} / \mathrm{GO}-\mathrm{NH}_{2}$ and (c) $\mathrm{H}_{3} \mathrm{PMo}_{12} \mathrm{O}_{40}$ and (d) $\mathrm{Fe}_{3} \mathrm{O}_{4} / \mathrm{GO}-\mathrm{NH}_{2} / \mathrm{H}_{3} \mathrm{PMo}_{12} \mathrm{O}_{40}$.

Figure 4 presents the Raman spectra of $\mathrm{GO}, \mathrm{Fe}_{3} \mathrm{O}_{4} /$ GO- $\mathrm{NH}_{2}$ and $\mathrm{Fe}_{3} \mathrm{O}_{4} / \mathrm{GO}-\mathrm{NH}_{2} / \mathrm{H}_{3} \mathrm{PMo}_{12} \mathrm{O}_{40}$. All the samples display the characteristic $\mathrm{D}\left(\mathrm{sp}^{3}\right.$ carbon atoms of disorders and defects) and $\mathrm{G}$ bands ( $\mathrm{sp}^{2}$ carbon atoms in graphitic sheets). ${ }^{64,65}$ As compared with the $\mathrm{D}$ and $\mathrm{G}$ bands of pure GO (D, $\left.1318 \mathrm{~cm}^{-1} ; \mathrm{G}, 1590 \mathrm{~cm}^{-1}\right)$, the two bands of $\mathrm{Fe}_{3} \mathrm{O}_{4} / \mathrm{GO}-\mathrm{NH}_{2}$ shift to $\mathrm{D}, 1315 \mathrm{~cm}^{-1}$ and $\mathrm{G}, 1588 \mathrm{~cm}^{-1}$, suggesting the successful silylanization of GO with APTES. After anchoring the $\mathrm{H}_{3} \mathrm{PMo}_{12} \mathrm{O}_{40}$ on the $\mathrm{Fe}_{3} \mathrm{O}_{4} / \mathrm{GO}$ $\mathrm{NH}_{2}$, further shifts in $\mathrm{D}$ and $\mathrm{G}$ bands are found $(\mathrm{D}, 1311$ 
$\mathrm{cm}^{-1}$ and $\mathrm{G}, 1592 \mathrm{~cm}^{-1}$ ). These shifts in Raman peaks can be attributed to strong interaction between $\mathrm{PMo}_{12} \mathrm{O}_{40}{ }^{3-}$ anion and positively charged $\mathrm{Fe}_{3} \mathrm{O}_{4} / \mathrm{GO}-\mathrm{NH}_{3}{ }^{+}$in $\mathrm{Fe}_{3} \mathrm{O}_{4} / \mathrm{GO}$ $\mathrm{NH}_{2} / \mathrm{H}_{3} \mathrm{PMo}_{12} \mathrm{O}_{40}$ hybrid, ${ }^{66}$ which is consistent with the FT-IR analysis. In addition, it is shown that the D/G intensity ratios of $\mathrm{Fe}_{3} \mathrm{O}_{4} / \mathrm{GO}-\mathrm{NH}_{2}$ and $\mathrm{Fe}_{3} \mathrm{O}_{4} / \mathrm{GO}-\mathrm{NH}_{2} / \mathrm{H}_{3} \mathrm{P}-$ $\mathrm{Mo}_{12} \mathrm{O}_{40}$ are higher than that of GO, suggesting a higher level of disorder of the graphene layers during the functionalization process. ${ }^{67}$ Also, this is proposed to be caused by the reduction of $\mathrm{GO}$ during the syntheses of GO-NH and $\mathrm{Fe}_{3} \mathrm{O}_{4} / \mathrm{GO}-\mathrm{NH}_{2} / \mathrm{H}_{3} \mathrm{PMo}_{12} \mathrm{O}_{40}$ hybrid as confirmed by the XRD data. ${ }^{68}$ The peaks of Keggin structure did not appear, which indicated that $\mathrm{H}_{3} \mathrm{PMo}_{12} \mathrm{O}_{40}$ species on the $\mathrm{Fe}_{3} \mathrm{O}_{4} / \mathrm{GO}-\mathrm{NH}_{2}$ sample were in a high-dispersed state. This result was identical to the XRD results.

SEM images indicating the microstructural features of GO, $\mathrm{Fe}_{3} \mathrm{O}_{4}, \mathrm{Fe}_{3} \mathrm{O}_{4} / \mathrm{GO}-\mathrm{NH}_{2}$, and $\mathrm{Fe}_{3} \mathrm{O}_{4} / \mathrm{GO}-\mathrm{NH}_{2} / \mathrm{H}_{3} \mathrm{P}-$ $\mathrm{Mo}_{12} \mathrm{O}_{40}$ hybrid nanomaterial are shown in Figure 5. The SEM micrograph of pure GO in Figure 5(a) shows the highly porous and layered structure of GO having large stacks, possibly consisting of hundreds of GO nanosheets. It should also be noted that the surfaces of the GO sheets are quite flat and smooth. Figure 5(b) shows the SEM micrograph of sphere-like $\mathrm{Fe}_{3} \mathrm{O}_{4}$ nanoparticles. It is worthy to observe that the lateral size of graphitic nanosheets was not disrupted with the oxidation, The SEM image of $\mathrm{Fe}_{3} \mathrm{O}_{4} / \mathrm{GO}-\mathrm{NH}_{2}$ in Figure 5(c) clearly shows GO nanos-

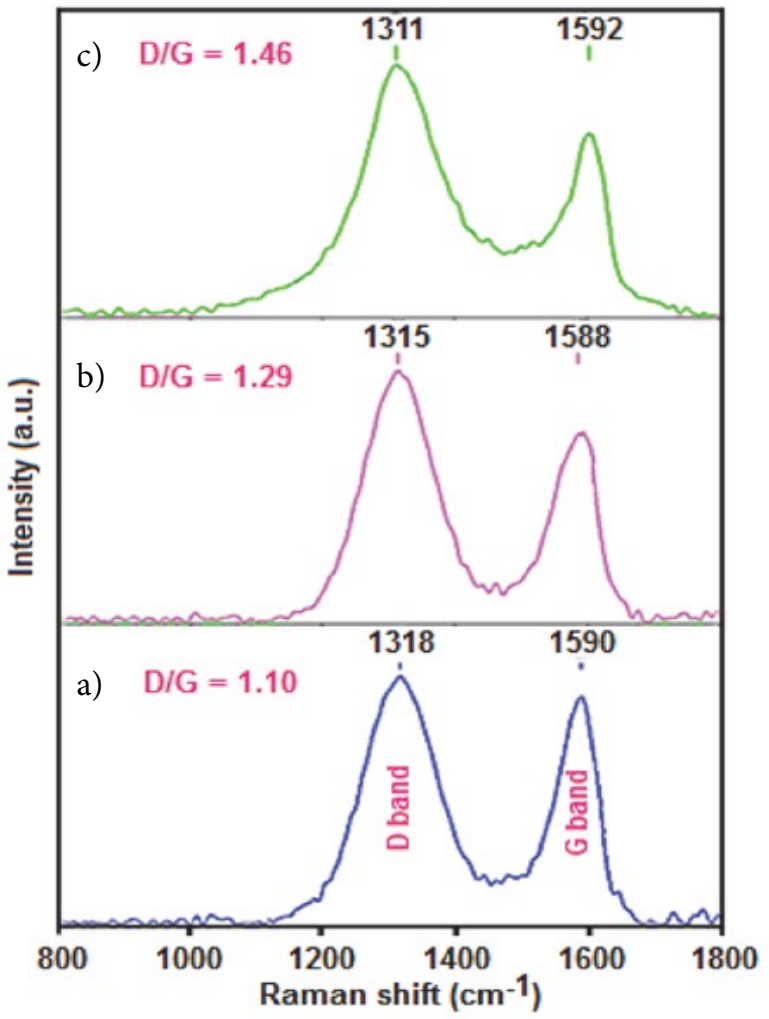

Figure 4. Raman spectra of (a) $\mathrm{GO}$, (b) $\mathrm{Fe}_{3} \mathrm{O}_{4} / \mathrm{GO}-\mathrm{NH}_{2}$ and (c) $\mathrm{Fe}_{3} \mathrm{O}_{4} / \mathrm{GO}-\mathrm{NH}_{2} / \mathrm{H}_{3} \mathrm{PMo}_{12} \mathrm{O}_{40}$.
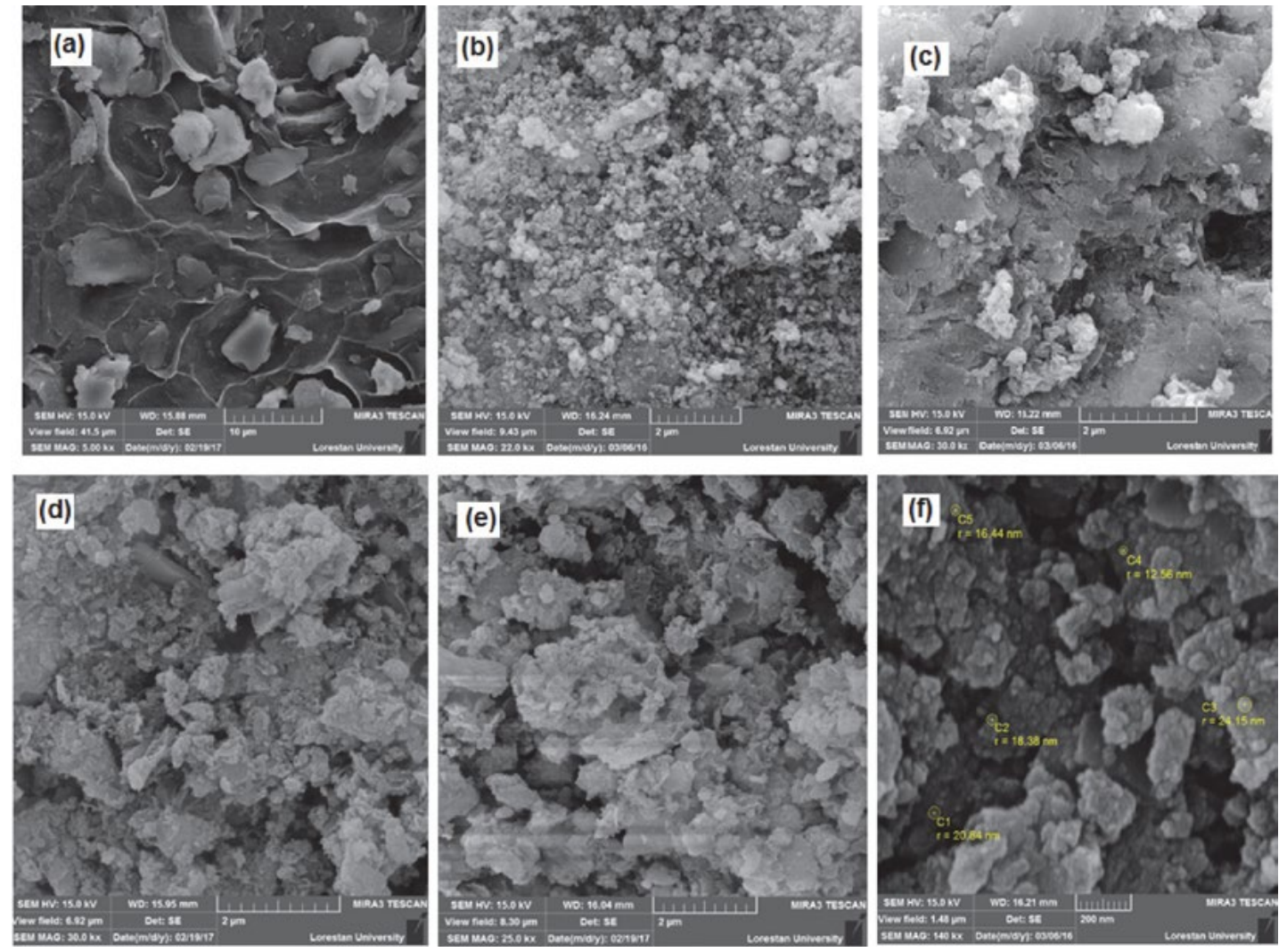

Figure 5. $\mathrm{SEM}$ images of (a) GO, (b) $\mathrm{Fe}_{3} \mathrm{O}_{4}$, (c) $\mathrm{Fe}_{3} \mathrm{O}_{4}-\mathrm{GO}$, (d) $\mathrm{Fe}_{3} \mathrm{O}_{4} / \mathrm{GO}-\mathrm{NH}_{2}$, and (e)-(f) $\mathrm{Fe}_{3} \mathrm{O}_{4} / G \mathrm{GO}-\mathrm{NH}_{2} / \mathrm{H}_{3} \mathrm{PMo}_{12} \mathrm{O}_{40}$ hybrid nanomaterial.

Farhadi et al.: Magnetically Recyclable $\mathrm{Fe}_{3} \mathrm{O}_{4} / G \mathrm{O}-\mathrm{NH}_{2} / \mathrm{H}_{3} \mathrm{PMo}_{12} \mathrm{O}_{40} \quad \ldots$ 
heets were successfully decorated with the $\mathrm{Fe}_{3} \mathrm{O}_{4}$ nanoparticles consisting of small and elongated grains. It was found that the average size of $\mathrm{Fe}_{3} \mathrm{O}_{4}$ nanoparticles was in the range of 20-30 nm. Figure 5(d)-(f) shows the morphology of the $\mathrm{Fe}_{3} \mathrm{O}_{4} / \mathrm{GO}-\mathrm{NH}_{2} / \mathrm{H}_{3} \mathrm{PMo}_{12} \mathrm{O}_{40}$ hybrid nanomaterial. As can be seen, agglomerated $\mathrm{Fe}_{3} \mathrm{O}_{4}$ and $\mathrm{PMo}_{12}$ nanoparticles completely covered the surfaces of large graphene sheets. It should also be noted that the micropores between the graphene sheets were evenly filled up with the $\mathrm{Fe}_{3} \mathrm{O}_{4}$ nanoparticles as clearly seen in the images of stack edges given in Figure 5(d)-(f). All the micrographs of the hybrid nanomaterial clearly indicated that the surface properties of the modified GO product were strongly affected. Opposite to pure GO, the surfaces of GO nanosheets in the hybrid nanomaterial are rough, and the edges are highly crumpled. It can be concluded that microstructural properties of $\mathrm{Fe}_{3} \mathrm{O}_{4} / \mathrm{GO}-\mathrm{NH}_{2} / \mathrm{H}_{3} \mathrm{PMo}_{12} \mathrm{O}_{40}$ hybrid nanomaterial encourage preparing the highly porous, magnetically active and structurally layered nanomaterials.

AFM is a beneficial tool for studying various morphological features and parameters, since it has the advantage of probing in deep insights of surface topography qualitatively due to its both lateral and vertical nanometer scale spatial resolution. The AFM images in Figure 6 display the surface morphology of the $\mathrm{Fe}_{3} \mathrm{O}_{4} / \mathrm{GO}-\mathrm{NH}_{2} / \mathrm{H}_{3} \mathrm{P}-$ $\mathrm{Mo}_{12} \mathrm{O}_{40}$. As observed in Figure 6(a), the AFM image reveals the appearance of sphere-like nanoparticles and their respective particle size and morphology clearly were close to those determined by the SEM images. As can be seen from Figure 6(b), the surface of the composite showed a porous and uniform packed structure with size (height) of particles on the grapheme sheet to be approximately 20 $\mathrm{nm}$. Thus, the $\mathrm{Fe}_{3} \mathrm{O}_{4} / \mathrm{GO}-\mathrm{NH}_{2} / \mathrm{H}_{3} \mathrm{PMo}_{12} \mathrm{O}_{40}$ could provide a rough and coarse surface with porosity for adsorption uses. The results are in good agreement with BET results and SEM images.
Further investigation was carried out by energy dispersive X-ray spectroscopy (EDX) to characterize the composition of the as-prepared $\mathrm{Fe}_{3} \mathrm{O}_{4} / \mathrm{GO}-\mathrm{NH}_{2} / \mathrm{H}_{3} \mathrm{PMo}_{12} \mathrm{O}_{40}$ hybrid nanomaterial. Figure 7(a)-(i) show the EDX spectrum and a representative SEM image of the hybrid nanomaterial with corresponding EDX elemental mappings. The presence of $\mathrm{C}, \mathrm{N}, \mathrm{Si}, \mathrm{O}, \mathrm{Fe}, \mathrm{P}$, and Mo elements in the composite can be proved by the EDX elemental spectrum (Figure 7(a)). As presented in Figure 7(b)-(f), the corresponding elemental mapping distribution shows the existence of $\mathrm{C}, \mathrm{N}, \mathrm{Si}, \mathrm{O}, \mathrm{Fe}, \mathrm{P}$, and Mo. From the maps, it can be seen that the elements are uniformly distributed over the hybrid nanomaterial, confirming the homogeneity of the sample. The $\mathrm{P}$ and Mo elements were from $\mathrm{H}_{3} \mathrm{PMo}_{12} \mathrm{O}_{40}$ and the results further indicate that the $\mathrm{H}_{3} \mathrm{PMo}_{12} \mathrm{O}_{40}$ particles were successfully supported on the surface of the $\mathrm{Fe}_{3} \mathrm{O}_{4} / \mathrm{GO}-\mathrm{NH}_{2}$.

The magnetic properties of the pure $\mathrm{Fe}_{3} \mathrm{O}_{4}$ and $\mathrm{Fe}_{3} \mathrm{O}_{4} /$ GO- $\mathrm{NH}_{2} / \mathrm{H}_{3} \mathrm{PMo}_{12} \mathrm{O}_{40}$ samples were investigated by VSM at room temperature, and the magnetic hysteresis loops are depicted in Figure 8. It is clear that both $\mathrm{Fe}_{3} \mathrm{O}_{4}$ and the $\mathrm{Fe}_{3} \mathrm{O}_{4} / \mathrm{GO}-\mathrm{NH}_{2} / \mathrm{H}_{3} \mathrm{PMo}_{12} \mathrm{O}_{40}$ composite are soft magnetic materials due to their coercivity (Hc) of zero. ${ }^{69}$ Moreover, they are also superparamagnetic materials, as their magnetic hysteresis loops passed through the origin of the coordinates. The saturation magnetization values of $\mathrm{Fe}_{3} \mathrm{O}_{4}$ and $\mathrm{Fe}_{3} \mathrm{O}_{4} / \mathrm{GO}-\mathrm{NH}_{2} / \mathrm{H}_{3} \mathrm{PMo}_{12} \mathrm{O}_{40}$ are 27.50 and $9.16 \mathrm{emu} / \mathrm{g}$, respectively. The saturation magnetization of the magnetic composite decreases by approximately $70 \%$ compared with that of pure $\mathrm{Fe}_{3} \mathrm{O}_{4}$, which can be attributed to the less magnetic source component $\left(\mathrm{Fe}_{3} \mathrm{O}_{4}\right)$ per gram in the composite sample. However, the saturation magnetization of the composite could satisfy the requirements of easy separation in the suspension solution using an extra magnet after reaction as shown in the inset of Figure 8. Thus, the $\mathrm{Fe}_{3} \mathrm{O}_{4} / \mathrm{GO}$ $\mathrm{NH}_{2} / \mathrm{H}_{3} \mathrm{PMo}_{12} \mathrm{O}_{40}$ composite can be easily separated using a magnetic separation process after being used for the removal of dye pollutants from aqueous solutions.
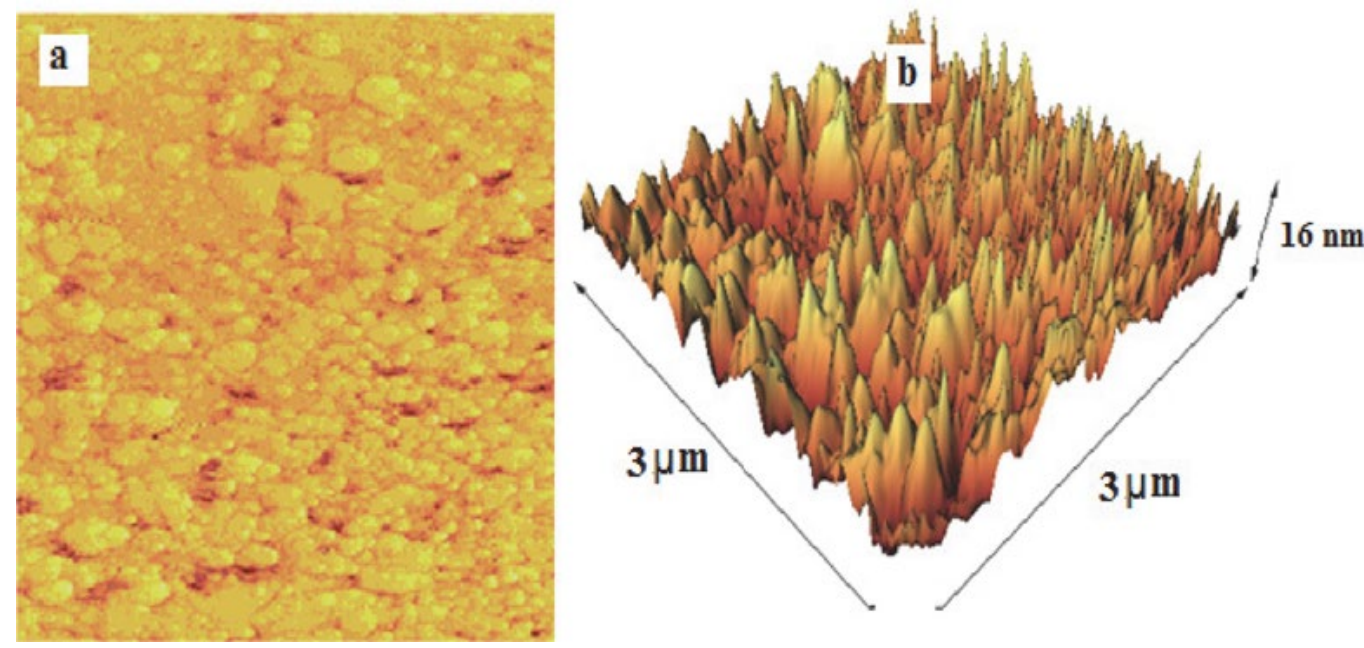

Figure 6. (a) AFM image and (b) height profile of $\mathrm{Fe}_{3} \mathrm{O}_{4} / \mathrm{GO}-\mathrm{NH}_{2} / \mathrm{H}_{3} \mathrm{PMo}_{12} \mathrm{O}_{40}$ in a three dimensional image. 

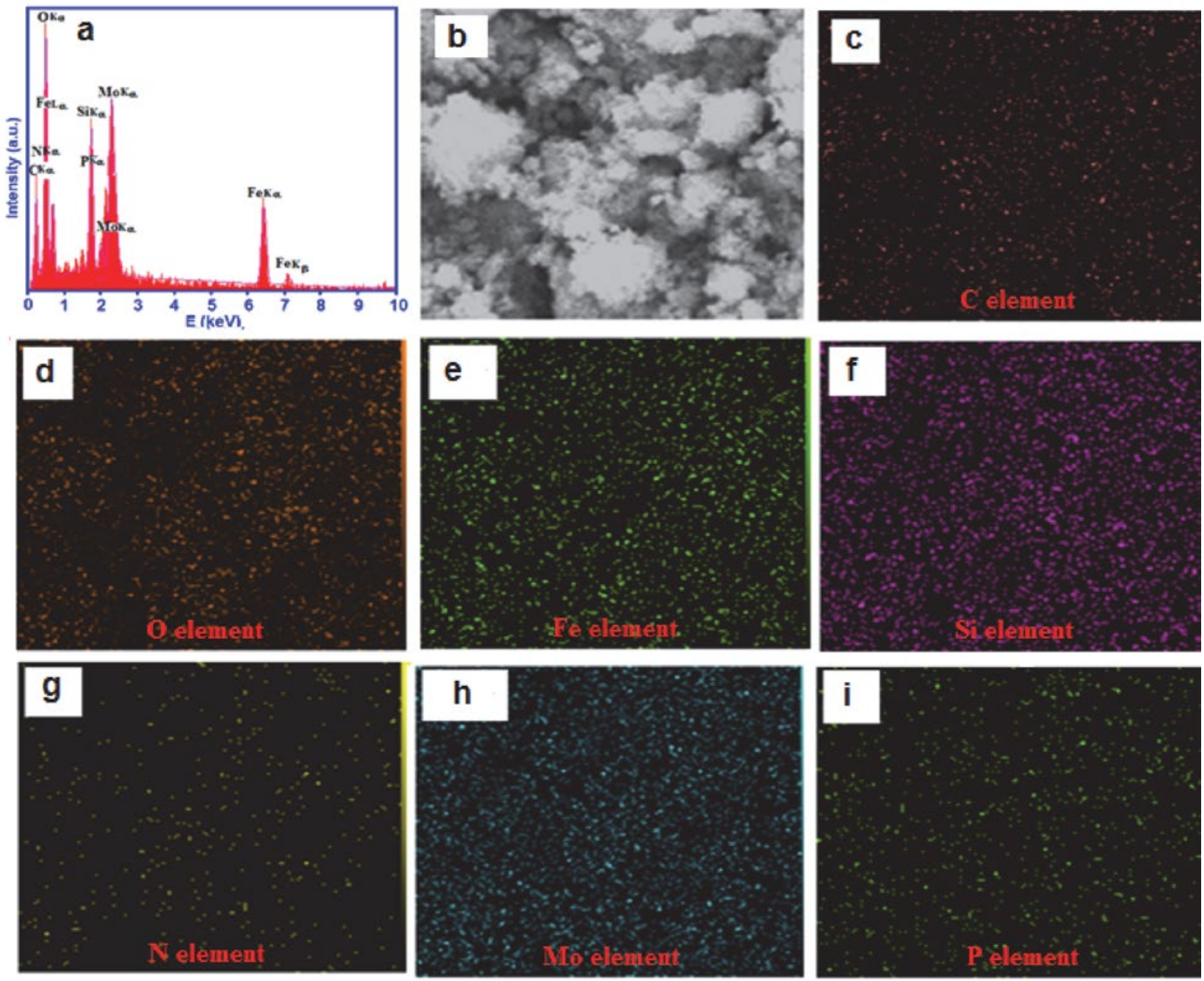

Figure 7. (a) EDX spectrum, and (b)-(i) a representative SEM image of the $\mathrm{Fe}_{3} \mathrm{O}_{4} / \mathrm{GO}-\mathrm{NH}_{2} / \mathrm{H}_{3} \mathrm{PMo}_{12} \mathrm{O}_{40}$ hybrid nanomaterial with corresponding EDX elemental mappings.

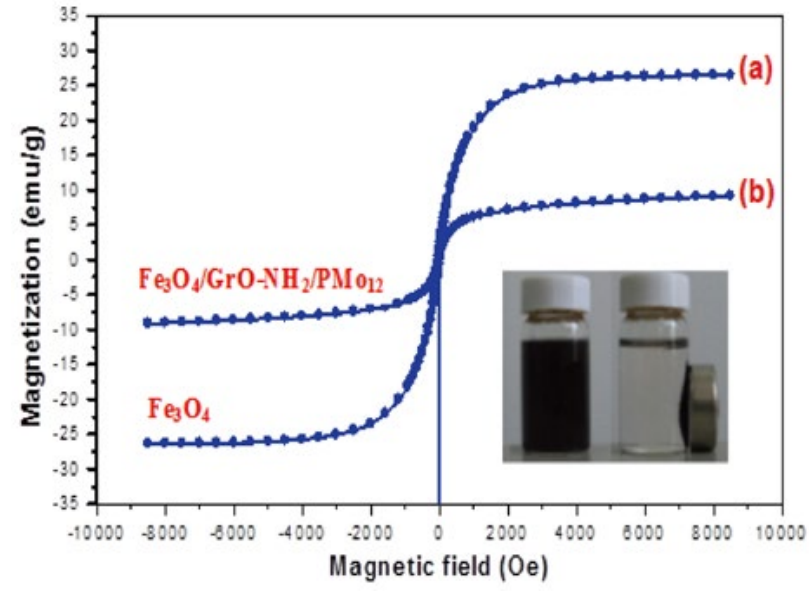

Figure 8. Magnetic hysteresis loop of (a) $\mathrm{Fe}_{3} \mathrm{O}_{4}$ and (b) $\mathrm{Fe}_{3} \mathrm{O}_{4} / \mathrm{GrO}$ $\mathrm{NH}_{2} / \mathrm{H}_{3} \mathrm{PMo}_{12} \mathrm{O}_{40}$ at room temperature. The inset shows the behaviour of the nanocomposite under an external magnetic field.
$\mathrm{N}_{2}$ adsorption/desorption measurements were performed to investigate specific surface area and the pore size distribution of the $\mathrm{Fe}_{3} \mathrm{O}_{4} / \mathrm{GO}-\mathrm{NH}_{2} / \mathrm{H}_{3} \mathrm{PMo}_{12} \mathrm{O}_{40}$. As can be seen in Figure 9(a), the nitrogen adsorption isotherm is a typical type IV curve with a fine H1-type hysteresis loop in the range of $\mathrm{ca} .0 .8-1.0 \mathrm{p} / \mathrm{p}_{0}$, indicating the existence of mesoporous structure. ${ }^{70,71}$ The BET surface area is measured to be $76.36 \mathrm{~m}^{2} / \mathrm{g}$ that is much higher than the value of pure POM $\left(\leq 10 \mathrm{~m}^{2} / \mathrm{g}\right)$. In addition, the total pore volume is $0.01 \mathrm{~cm}^{3} / \mathrm{g}$ and according to the corresponding Barrett-Joyner-Halenda (BJH) pore size distribution curve in Figure 9(b), the pore size distribution of the $\mathrm{Fe}_{3} \mathrm{O}_{4} / \mathrm{GO}-\mathrm{NH}_{2} / \mathrm{H}_{3} \mathrm{PMo}_{12} \mathrm{O}_{40}$ shows a peak centered at around $2.28 \mathrm{~nm}$. Such porosity of $\mathrm{Fe}_{3} \mathrm{O}_{4} / \mathrm{GO}-\mathrm{NH}_{2} / \mathrm{H}_{3} \mathrm{P}-$ $\mathrm{Mo}_{12} \mathrm{O}_{40}$ composite can improve the adsorption performance. It can be concluded that introduction of magnetic $\mathrm{Fe}_{3} \mathrm{O}_{4} / \mathrm{GO}-\mathrm{NH}_{2}$ has a good effect on the structure of $\mathrm{H}_{3} \mathrm{P}-$ 

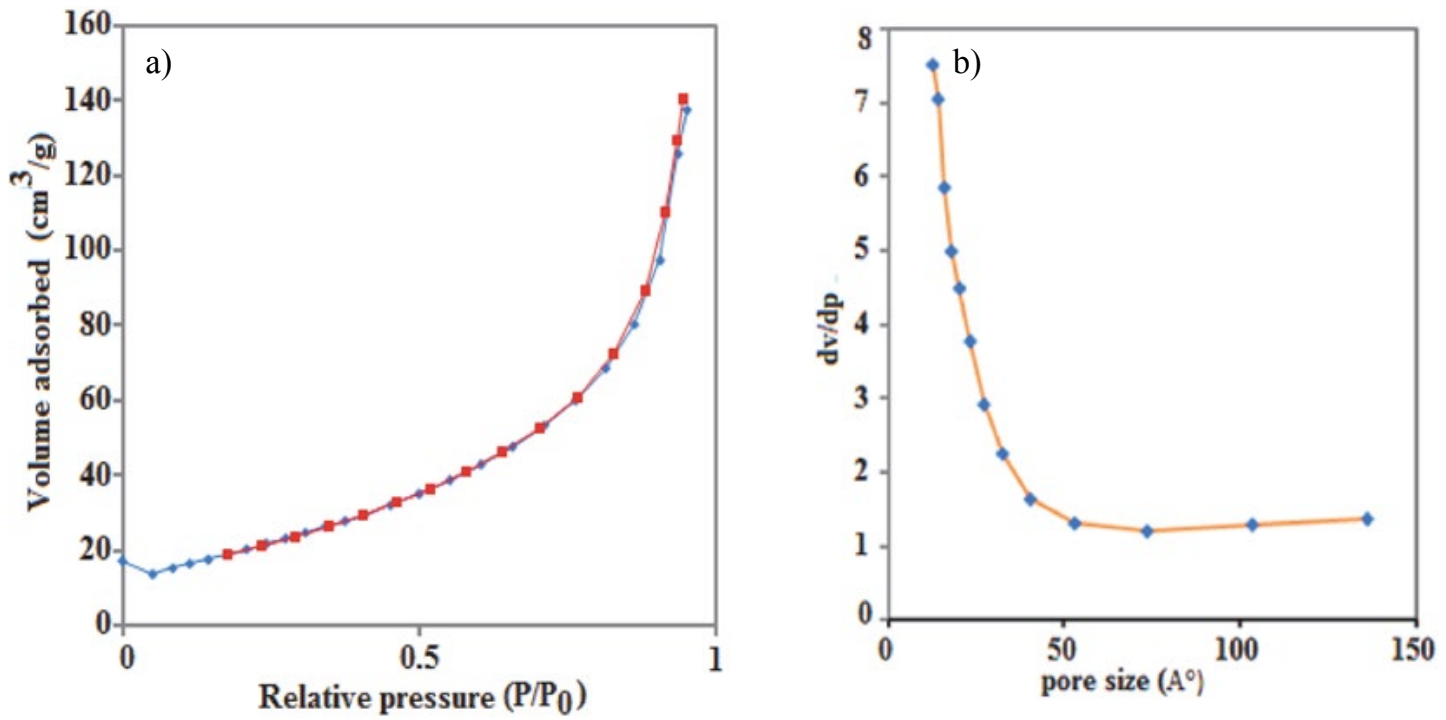

Figure 9. (a) $\mathrm{N}_{2}$ adsorption-desorption isotherm and (b) pore size distribution of $\mathrm{Fe}_{3} \mathrm{O}_{4} / \mathrm{GO}-\mathrm{NH}_{2} / \mathrm{H}_{3} \mathrm{PMo}_{12} \mathrm{O}_{40}$.

$\mathrm{Mo}_{12} \mathrm{O}_{40}$ and increases the surface area and porosity of POM which are all useful factors for improving the adsorption performance.

a)

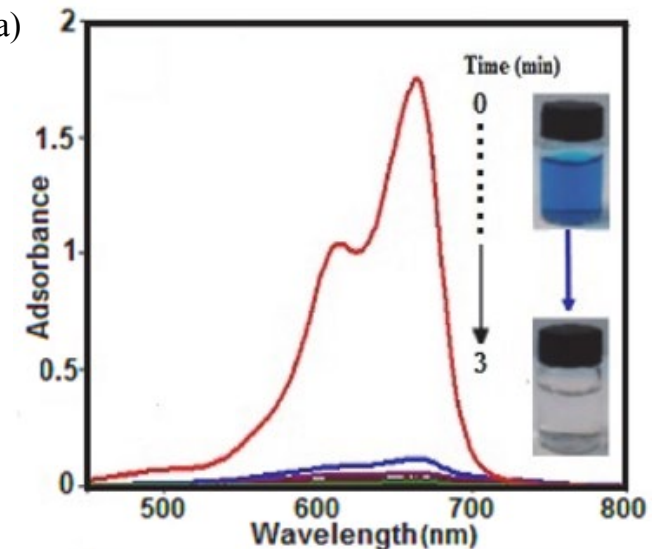

c)

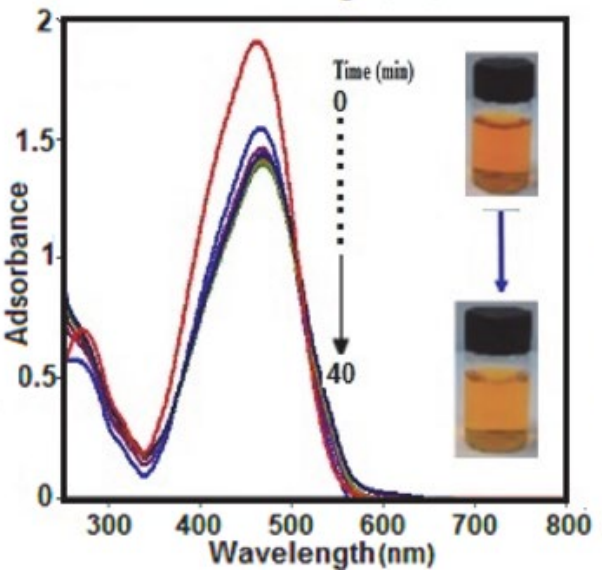

\section{2. Dye Adsorption Studies}

To evaluate the adsorption capability of $\mathrm{Fe}_{3} \mathrm{O}_{4} / \mathrm{GO}$ $\mathrm{NH}_{2} / \mathrm{H}_{3} \mathrm{PMo}_{12} \mathrm{O}_{40}$ hybrid nanomaterial for removing or-

b)

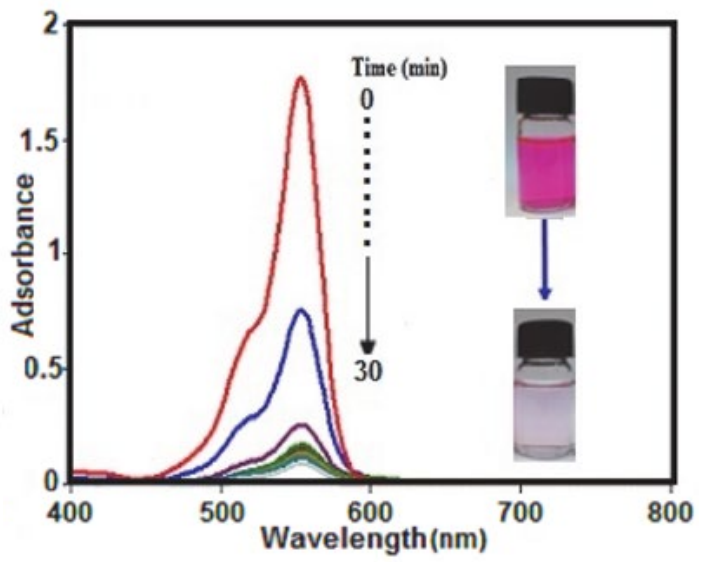

d)

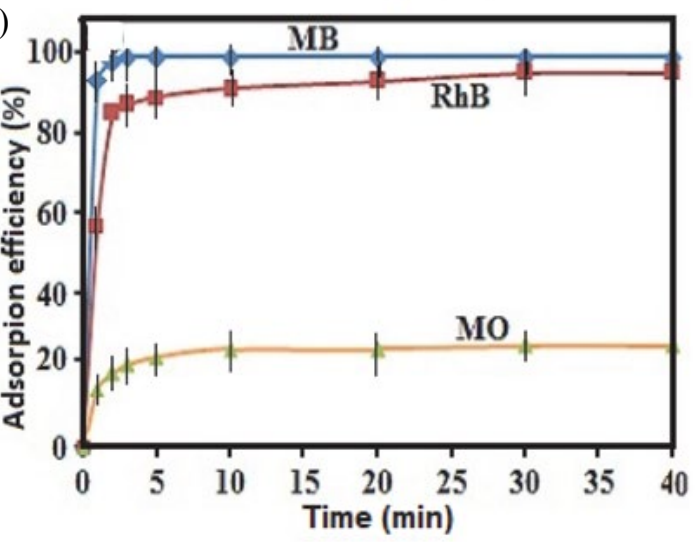

Figure 10. UV-vis spectral changes of dyes aqueous solutions over $\mathrm{Fe}_{3} \mathrm{O}_{4} / \mathrm{GrO}-\mathrm{NH}_{2} / \mathrm{H}_{3} \mathrm{PMo}_{12} \mathrm{O}_{40}$ at different time intervals: (a) $\mathrm{MB}$ dye, (b) RhB dye, (c) MO dye and (d) Comparison of adsorption efficiency (\%) of dyes as function of time. Conditions: [dye] $=25 \mathrm{mg} / \mathrm{L}, 50 \mathrm{~mL}$; [Adsorbent] $=25 \mathrm{mg} / 50$ $\mathrm{mL}$ at $25^{\circ} \mathrm{C}$. 
ganic dyes from contaminated water, three organic pollutants (MB, RhB, and MO) with different sizes and charges were selected for experiments. The adsorption was monitored using the characteristic absorption peak, which is 664, 553 and $463 \mathrm{~nm}$ for $\mathrm{MB}, \mathrm{RhB}$, and MO, respectively. The decrease in the intensity of these characteristic peaks with adsorption time indicates the decrease in the dye amount in the solution. The time dependent UV-Vis absorption spectra of dyes in the presence of the $\mathrm{Fe}_{3} \mathrm{O}_{4} / \mathrm{GO}$ $\mathrm{NH}_{2} / \mathrm{H}_{3} \mathrm{PMo}_{12} \mathrm{O}_{40}$ are shown in Figure 10(a)-(c). The digital images and UV-Vis spectroscopic results show that the characteristic absorption peaks of cationic $\mathrm{MB}$ and $\mathrm{RhB}$ dyes at 664 and $553 \mathrm{~nm}$ almost completely disappeared within 3 and $30 \mathrm{~min}$, respectively. As it can be seen in Figure $10(\mathrm{c})$, the characteristic absorbance band of $\mathrm{MO}$ at 463 $\mathrm{nm}$ decreased slightly even after $40 \mathrm{~min}$ with negligible fading of the orange color. The results show that the hybrid nanomaterial is a poor absorbent for anionic $\mathrm{MO}$ dye from aqueous solution. As compared in Figure 10(d), it is clear that the $\mathrm{Fe}_{3} \mathrm{O}_{4} / \mathrm{GO}-\mathrm{NH}_{2} / \mathrm{H}_{3} \mathrm{PMo}_{12} \mathrm{O}_{40}$ has different adsorption abilities toward different organic dyes. The adsorption efficiency for $\mathrm{MB}$ is $100 \%$ in $3 \mathrm{~min}$ and for $\mathrm{RhB}$ is $96 \%$ in $30 \mathrm{~min}$. The removal of $\mathrm{MO}$ dye is less than $25 \%$ after 40 min. Particularly, the adsorption rate of $50 \mathrm{~mL}$ of $25 \mathrm{mg} / \mathrm{L}$ $\mathrm{MB}$ and $\mathrm{RhB}$ solutions quickly reached $100 \%$ and $85 \%$, respectively, in the first three minutes. The different effects on removal of dyes can be related to the structure of the dye molecules and the adsorbent material. Firstly, POMs are a kind of hydrophilic metal-oxo cluster compounds. The hydrophilic/hydrophobic property of the hybrid framework is modulated by loading the $\mathrm{H}_{3} \mathrm{PMo}_{12} \mathrm{O}_{40}$ molecules, which allows the ingress and egress of the dye molecules. Secondly, POMs with a large number of negative charges in the hybrid may have a stronger force with the positive charges of dyes. So, the hybrid has demonstrated a good adsorption property toward the cationic dye molecules $\mathrm{MB}$ and $\mathrm{RhB}$. However, the removal percent of $\mathrm{RhB}$ is relatively low due to the large volume of the $\mathrm{RhB}$ molecules, which caused a steric hindrance with the active adsorption sites on the hybrid. Although MO molecules are small enough for ingress and egress, a little uptake capacity of MO was observed as the negative charge of this dye molecule. There are like-charges that repel each other between the POM caged in hybrid and MO.

To further demonstrate the role of anionic $\mathrm{H}_{3} \mathrm{PMo}_{12} \mathrm{O}_{40}$ cluster in the hybrid nanomaterial, a series of control experiments were carried out using $\mathrm{Fe}_{3} \mathrm{O}_{4}, \mathrm{Fe}_{3} \mathrm{O}_{4} / \mathrm{GO}, \mathrm{Fe}_{3} \mathrm{O}_{4} /$ GO-NH , and pure $\mathrm{H}_{3} \mathrm{PMo}_{12} \mathrm{O}_{40}$ samples as adsorbents for removing $\mathrm{MB}$ dye. As shown in Figure 11, the adsorption efficiencies of these samples toward the MB dye are $40-78 \%$ albeit after long adsorption times of 30-40 min. Apparently, the removal efficiencies and rates of these materials are smaller than those of the $\mathrm{Fe}_{3} \mathrm{O}_{4} / \mathrm{GrO}-\mathrm{NH}_{2} / \mathrm{H}_{3} \mathrm{PMo}_{12} \mathrm{O}_{40}$ hybrid nanomaterial for cationic $\mathrm{MB}$ dye $(100 \%$ in $3 \mathrm{~min})$. Therefore, there is still merit in exploring the hybrid nanomaterial as efficient adsorbent toward cationic MB dye.

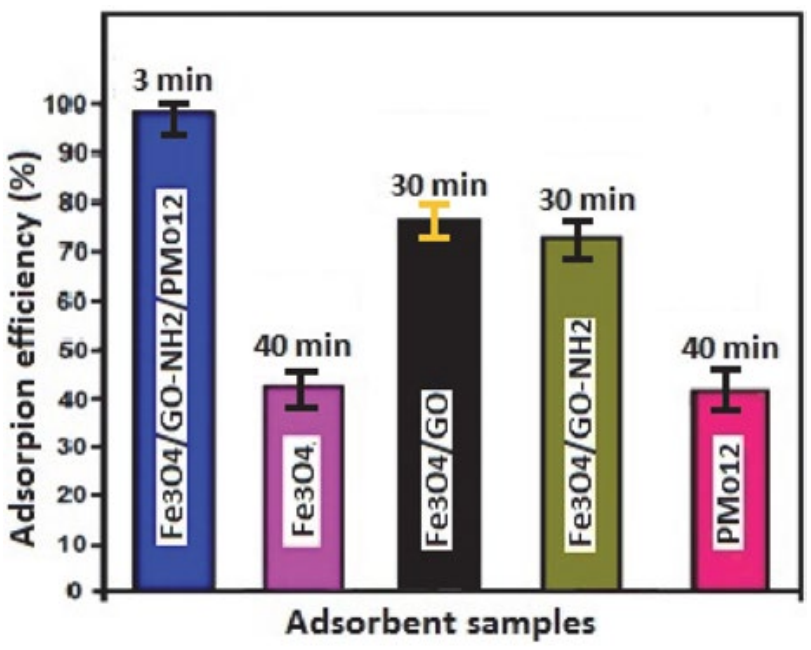

Figure 11. Adsorption efficiency (\%) of the MB dye in the presence of different adsorbent samples.

\section{3. Selective Adsorption Ability of the Hybrid Nanomaterial for the Mixed Organic Dyes}

Selective adsorption and separation of the specific dye are more attractive and challenging in the process of dye-wastewater treatment. In this study, in view of the large uptake capacity of $\mathrm{MB}$ and $\mathrm{RhB}$ in $\mathrm{Fe}_{3} \mathrm{O}_{4} / \mathrm{GO}-\mathrm{NH}_{2} /$ $\mathrm{H}_{3} \mathrm{PMo}_{12} \mathrm{O}_{40}$, it can be anticipated that the composite material may also have an outstanding adsorption and separation behavior in the treatment of mixture of dyes. The selective uptake of dyes was tested using the $\mathrm{MB} / \mathrm{MO}$ mixture $\left(50 \mathrm{~mL}, \mathrm{C}_{0(\mathrm{MB})}=C_{0(\mathrm{MO})}=25 \mathrm{mg} / \mathrm{L}\right)$ and $\mathrm{MB} / \mathrm{RhB}$ mixture $\left(50 \mathrm{~mL}, \mathrm{C}_{0(\mathrm{MB})}=\mathrm{C}_{0(\mathrm{MO})}=25 \mathrm{mg} / \mathrm{L}\right)$ with $25 \mathrm{mg}$ of $\mathrm{Fe}_{3} \mathrm{O}_{4} / \mathrm{GO}-\mathrm{NH}_{2} / \mathrm{H}_{3} \mathrm{PMo}_{12} \mathrm{O}_{40}$ as adsorbent. The process was monitored by UV-Vis spectroscopy. As MB and MO are similar in molecule size, the preferable uptake of $\mathrm{MB}$ from the $\mathrm{MB} / \mathrm{MO}$ mixture may be assigned to the anionic nature of the composite $\mathrm{Fe}_{3} \mathrm{O}_{4} / \mathrm{GO}-\mathrm{NH}_{2} / \mathrm{H}_{3} \mathrm{PMo}_{12} \mathrm{O}_{40}$, as shown in Figure 12(a). For comparison, cationic $\mathrm{RhB}$ was selected to mix with anionic $\mathrm{MO}\left(50 \mathrm{~mL}, C_{0(\mathrm{MO})}=C_{0(\mathrm{RhB})}=\right.$ $25 \mathrm{mg} / \mathrm{L}$ ). Results revealed that $\mathrm{RhB}$ was also preferably adsorbed on the composite material from the $\mathrm{MO} / \mathrm{RhB}$ mixture as illustrated in Figure 12(b), which may imply that the uptake of dyes is heavily influenced by molecule size along with charges. ${ }^{72,73}$ To further validate this point, a ternary mixture of $\mathrm{MB}, \mathrm{RhB}$, and $\mathrm{MO}\left(50 \mathrm{~mL}, \mathrm{C}_{0(\mathrm{MB})}=\right.$ $\mathrm{C}_{0(\mathrm{MO})}=\mathrm{C}_{0(\mathrm{RhB})}=25 \mathrm{mg} / \mathrm{L}$ ) with $25 \mathrm{mg}$ of the adsorbent was investigated. As exhibited in Figure 12(c), the representative peaks of $\mathrm{MB}$ and $\mathrm{RhB}$ all disappeared quickly in mixed dyes and only the characteristic absorption peaks of $\mathrm{MO}$ were left, suggesting that $\mathrm{Fe}_{3} \mathrm{O} / \mathrm{GO}-\mathrm{NH}_{2} / \mathrm{H}_{3} \mathrm{PMo}_{12} \mathrm{O}_{40}$ could selectively capture cationic dyes when utilized in the corresponding ternary mixture. The same conclusion is displayed in the insets of Figure 12(a)-(c) and only the color of MO can be seen in the final solutions of mixed dyes. It can be attributed to the negative charge of this dye mol-

Farhadi et al.: Magnetically Recyclable $\mathrm{Fe}_{3} \mathrm{O}_{4} / \mathrm{GO}-\mathrm{NH}_{2} / \mathrm{H}_{3} \mathrm{PMo}_{12} \mathrm{O}_{40} \quad \ldots$ 

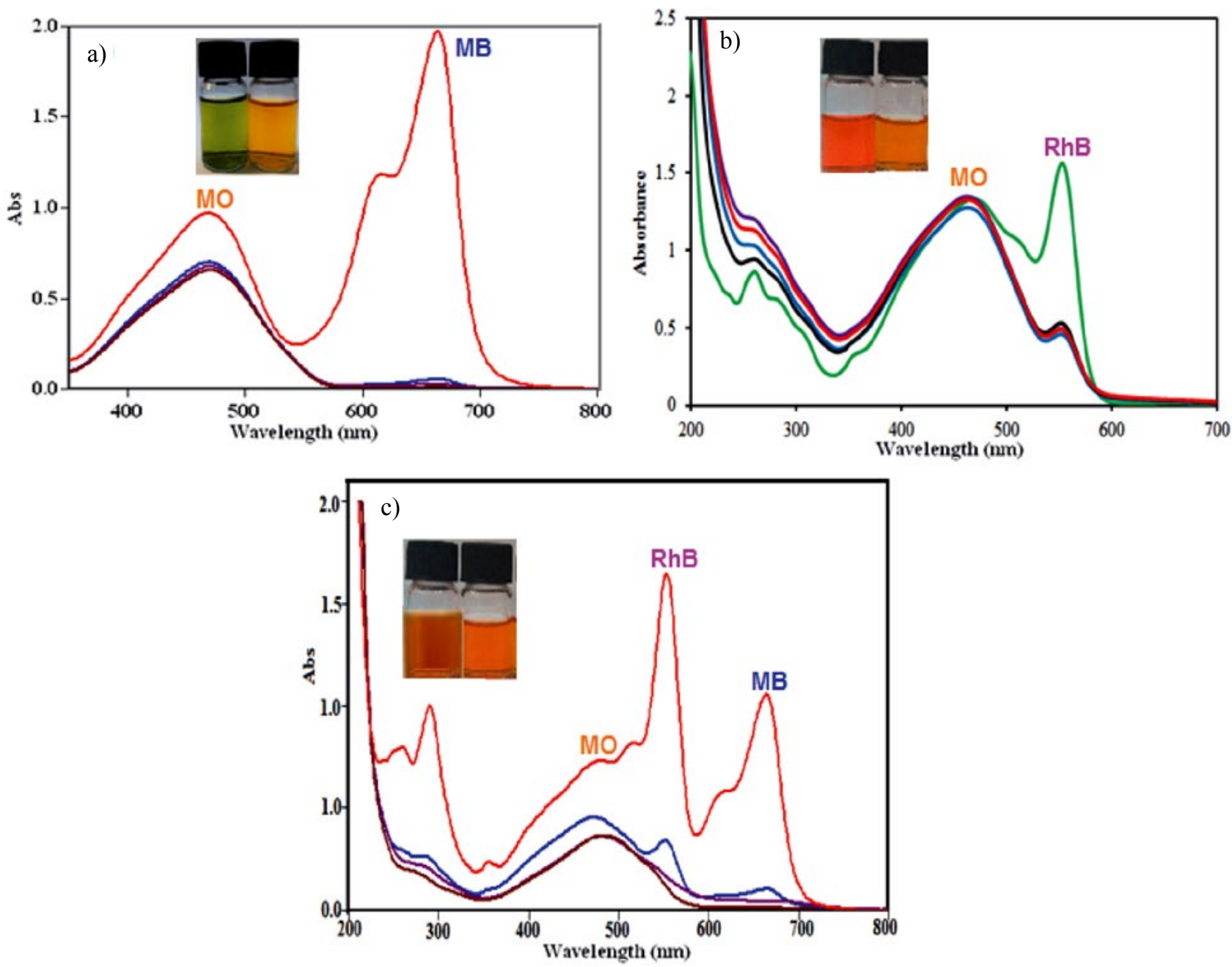

Figure 12. Selective adsorption ability of $\mathrm{Fe}_{3} \mathrm{O}_{4} / \mathrm{GO}-\mathrm{NH}_{2} / \mathrm{H}_{3} \mathrm{PMo}_{12} \mathrm{O}_{40}$ toward mixed dyes solution of (a) $\mathrm{MB}+\mathrm{MO},(\mathrm{b}) \mathrm{RhB}+\mathrm{MO},(\mathrm{c})$ $\mathrm{MB}+\mathrm{RhB}+\mathrm{MO}$. Conditions : $\mathrm{C}_{0}(\mathrm{MB})=\mathrm{C}_{0}(\mathrm{RhB})=\mathrm{C}_{0}(\mathrm{MO})=25 \mathrm{mg} / \mathrm{L}$ and adsorbent dose $=25 \mathrm{mg} / 50 \mathrm{~mL}$

ecule, which repels each other between $\mathrm{MO}$ and the $\mathrm{H}_{3} \mathrm{P}-$ $\mathrm{Mo}_{12} \mathrm{O}_{40}$ cluster in the hybrid nanomaterial. The slightly decreasing absorbance of $\mathrm{MO}$ is more likely to be adsorbed on the surface of adsorbent. The results further confirmed that the electrostatic attraction is the key factor for the occurrence of adsorption. Thus, $\mathrm{Fe}_{3} \mathrm{O}_{4} / \mathrm{GO}-\mathrm{NH}_{2} / \mathrm{H}_{3} \mathrm{PMo}_{12} \mathrm{O}_{40}$ composite nanomaterial is an environmental friendly, active adsorbent for removing different cationic organic pollutants after the immobilization of POM anion.

\section{4. The Reusability and Stability of the Hybrid Nanomaterial}

The stability and reusability of the adsorbents are an important standard for practical application. To verify whether the composite material is stable and recycled during the adsorption experiments, the cycle tests of $\mathrm{Fe}_{3} \mathrm{O}_{4} / \mathrm{GO}-\mathrm{NH}_{2} / \mathrm{H}_{3} \mathrm{PMo}_{12} \mathrm{O}_{40}$ on removing $\mathrm{MB}$ were explored. After each cycle, the adsorbent was completely separated by a magnet because of the magnetic property in water. Subsequently, the fast release process of the adsorbed MB was achieved by thoroughly washing the adsorbent with a dilute solution of $\mathrm{NaCl}$ and ethanol three times. Then, desorbed adsorbent was added to $50 \mathrm{~mL}$ of 25 $\mathrm{mg} / \mathrm{L} \mathrm{MB}$ solution under stirring. As described in Figure 13 , the composite nanomaterial showed almost identically rapid adsorption of $\mathrm{MB}$. After four cycles, the regenerated adsorbent was still able to remove $94 \% \mathrm{MB}$ from the aqueous solution. Thus, we may conclude that the composite nanomaterial can be reusable during the adsorption experiment.

The stability of this material is further discussed. As depicted in Fig. 14(a) and (b), the XRD pattern and FT-IR spectrum of the recovered adsorbent after the fourth run are consistent with those of the as-synthesized composite (see Figures 2(c) and 3(d)). These observations confirmed that the structure of the $\mathrm{Fe}_{3} \mathrm{O}_{4} / \mathrm{GO}-\mathrm{NH}_{2} / \mathrm{H}_{3} \mathrm{PMo}_{12} \mathrm{O}_{40}$ hybrid nanomaterial is stable under the reaction conditions and is not affected by the reactants. The morphology of the recycled adsorbent particles was also analyzed. Fig. 14(c) 


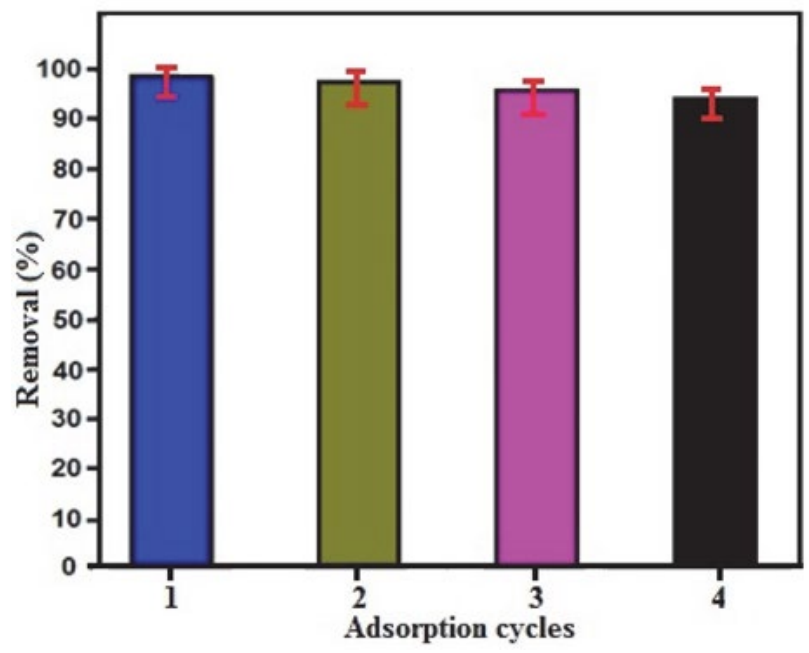

Figure 13. Recyclability of the $\mathrm{Fe}_{3} \mathrm{O}_{4} / \mathrm{GO}-\mathrm{NH}_{2} / \mathrm{H}_{3} \mathrm{PMo}_{12} \mathrm{O}_{40}$ hybrid nanomaterial in the removal of $\mathrm{MB}$ dye. shows a representative SEM image of the adsorbent after four cycles. It could be observed that the recovered adsorbent almost kept its initial size and morphology (see Figure 5(e) and (f)) and the surface of GO nanosheets was still decorated with $\mathrm{Fe}_{3} \mathrm{O}_{4}$ and $\mathrm{H}_{3} \mathrm{PMo}_{12} \mathrm{O}_{40}$ particles, revealing the strong binding between the $\mathrm{Fe}_{3} \mathrm{O}_{4}$ nanoparticles and $\mathrm{H}_{3} \mathrm{PMo}_{12} \mathrm{O}_{40}$ with $\mathrm{GO}$ nanosheets. We can also observe representative peaks of $\mathrm{C}, \mathrm{N}, \mathrm{O}, \mathrm{Si}, \mathrm{Fe}, \mathrm{P}$, and Mo from the EDX of the recovered $\mathrm{Fe}_{3} \mathrm{O}_{4} / \mathrm{GO}-\mathrm{NH}_{2} / \mathrm{H}_{3} \mathrm{PMo}_{12} \mathrm{O}_{40}$ (Figure 14(d)). Considering the above mentioned experiment results, we can conclude that the structure of the compound remained intact, which further confirms its excellent stability and recyclability.

The $\mathrm{Fe}_{3} \mathrm{O}_{4} / \mathrm{GO}-\mathrm{NH}_{2} / \mathrm{H}_{3} \mathrm{PMo}_{12} \mathrm{O}_{40}$ hybrid exhibited the maximum adsorption capacity of $426.7 \mathrm{mg} / \mathrm{g}$ when $100 \mathrm{mg}$ of $\mathrm{Fe}_{3} \mathrm{O}_{4} / \mathrm{GO}-\mathrm{NH}_{2} / \mathrm{H}_{3} \mathrm{PMo}_{12} \mathrm{O}_{40}$ was soaked in 100 $\mathrm{mL}$ of $500 \mathrm{mg} / \mathrm{L}$ aqueous $\mathrm{MB}$ solution for $2 \mathrm{~h}$. As can be seen in Table $1, \mathrm{Fe}_{3} \mathrm{O}_{4} / \mathrm{GO}-\mathrm{NH}_{2} / \mathrm{H}_{3} \mathrm{PMo}_{12} \mathrm{O}_{40}$ exhibits
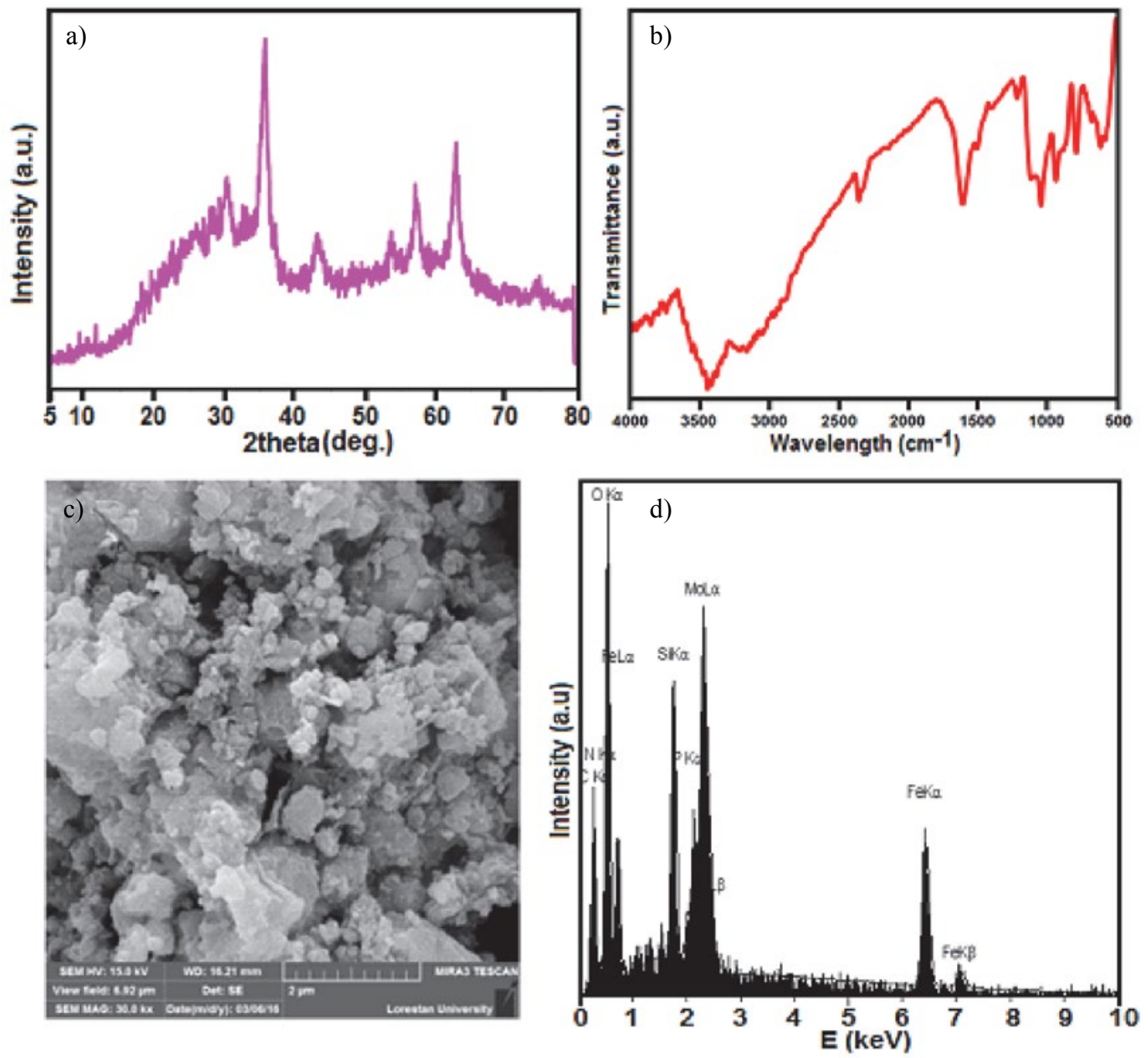

Figure 14. (a) XRD pattern, (b) FT-IR spectrum, (c) SEM image, and (d) EDX spectrum of the recovered $\mathrm{Fe}_{3} \mathrm{O}_{4} / \mathrm{GO}_{-} \mathrm{NH}_{2} / \mathrm{H}_{3} \mathrm{PMo}{ }_{12} \mathrm{O}_{40}$ hybrid nanomaterial after the fourth run. 
much higher uptake capacity of $\mathrm{MB}$, compared with the adsorbents that were reported. ${ }^{74-87}$ On the basis of the above observations and the characteristics of $\mathrm{Fe}_{3} \mathrm{O}_{4} / \mathrm{GO}$ $\mathrm{NH}_{2} / \mathrm{H}_{3} \mathrm{PMo}_{12} \mathrm{O}_{40}$ nanocomposite, we infer that the following factors could contribute to the increased adsorption capacity of this nanocomposite. On the one hand, the anchored aminopropyl groups and the presence of the well dispersed $\mathrm{Fe}_{3} \mathrm{O}_{4}$ and $\mathrm{H}_{3} \mathrm{PMo}_{12} \mathrm{O}_{40}$ nanoparticles on the $\mathrm{GO}$ nanosheets surface could act as spacers and thus prohibit the graphene sheets to restack. This directly results in significant increase of the specific surface area of graphene structures, which can be of great benefit to adsorption processes. This result is consistent with BET surface area data in Figure 9. On the other hand, the anchored $\mathrm{PMo}_{12} \mathrm{O}_{40}{ }^{3-}$ polyanions with a large number of negative charges in the ternary hybrid have a stronger attraction force with the positive charges of cationic dyes (e.g. MB). In fact, higher adsorption capacity of the $\mathrm{Fe}_{3} \mathrm{O}_{4} / \mathrm{GO}-\mathrm{NH}_{2} / \mathrm{H}_{3} \mathrm{PMo}_{12} \mathrm{O}_{40}$ is due to synergistic effect between $\mathrm{GO}$ nanosheets and $\mathrm{PMo}_{12} \mathrm{O}_{40}{ }^{3-}$ polyanions. Thus, this material is a promising adsorbent for the treatment of toxic organic pollutants in the dye-wastewater.

Table 1. Comparison of the adsorption capacities of MB onto some typical adsorbents.

\begin{tabular}{|c|c|c|c|}
\hline Entry & Adsorbent material & $\begin{array}{c}\text { Adsorption } \\
\text { capacity }(\mathrm{mg} / \mathrm{g})\end{array}$ & Ref. \\
\hline 1 & Activated carbon & 135 & 74 \\
\hline 2 & Nano- ZIF - 8 & 13.3 & 74 \\
\hline 3 & Zeolite & 10.86 & 75 \\
\hline 4 & $\mathrm{Fe}_{3} \mathrm{O}_{4} /$ graphene & 33.66 & 76 \\
\hline 5 & $\mathrm{H}_{3} \mathrm{PW}_{12} \mathrm{O}_{40} / \mathrm{ZIF}-8$ & 810 & 74 \\
\hline 6 & $\mathrm{H}_{3} \mathrm{PW}_{12} \mathrm{O}_{40} / \mathrm{Mn}^{\mathrm{III}}$ porphyrin & 10.5 & 77 \\
\hline 7 & Graphene & 153.83 & 78 \\
\hline 8 & $\mathrm{CoFe}_{2} \mathrm{O}_{4} / \mathrm{MWCNT}$ & 14.3 & 79 \\
\hline 9 & $\mathrm{H}_{6} \mathrm{P}_{2} \mathrm{~W}_{18} \mathrm{O}_{62} / \mathrm{MOF}-5$ & 51.81 & 80 \\
\hline 10 & $\mathrm{H}_{3} \mathrm{PW}_{12} \mathrm{O}_{40} / \mathrm{MIL}-101(\mathrm{Fe})$ & 473.7 & 81 \\
\hline 11 & $\mathrm{H}_{4} \mathrm{PW}_{11} \mathrm{~V} / \mathrm{MIL}-101(\mathrm{Cr})$ & 371 & 82 \\
\hline 12 & $(4-\mathrm{Hap})_{4}\left[\mathrm{Mo}_{8} \mathrm{O}_{26}\right]$ & 916.04 & 83 \\
\hline 13 & MOF/graphite oxide & 18 & 84 \\
\hline 14 & Carbon nanotubes & 46.2 & 85 \\
\hline 15 & MOF-235 & 187 & 86 \\
\hline 16 & Grapheme oxide (GO) & 144.92 & 87 \\
\hline 17 & Calcium alginate/GO & 188.81 & 87 \\
\hline 18 & $\mathrm{Fe}_{3} \mathrm{O}_{4} / \mathrm{GO}-\mathrm{NH}_{2} / \mathrm{H}_{3} \mathrm{PMo}_{12} \mathrm{O}_{40}$ & 426.7 & This work \\
\hline
\end{tabular}

\section{Conclusions}

In summary, the novel ternary hybrid nanomaterial $\mathrm{Fe}_{3} \mathrm{O}_{4} / \mathrm{GO}-\mathrm{NH}_{2} / \mathrm{H}_{3} \mathrm{PMo}_{12} \mathrm{O}_{40}$ was synthesized by a simple acid-base interaction between aminopropyl functionalized magnetic graphene oxide nanosheets and $\mathrm{H}_{3} \mathrm{PMo}_{12} \mathrm{O}_{40}$ and tested as a new adsorbent in the removal of $\mathrm{MB}, \mathrm{RhB}$, and MO dyes from aqueous solutions. The results confirmed that this adsorbent displayed much higher adsorp- tion capacity for cationic dyes and lower adsorption capacity for anionic dyes. This adsorption selectivity is due to the favorable electrostatic interactions between the adsorbents and cationic dyes. High adsorption capacity, compared with other adsorbents, accompanied by the ease of separation by an external magnetic field make the prepared hybrid a powerful separation tool to be utilized in wastewater treatment.

\section{Acknowledgements}

The authors gratefully acknowledge the Lorestan University Research Council and Iran Nanotechnology Initiative Council (INIC) for their financial support.

\section{References}

1. S. Kaur, R. Gopal, W. J. Ng, S. Ramakrishna and T. Matsuura, MRS Bull., 2008, 33, 21-26. DOI:10.1557/mrs2008.10

2. H. W. Liang, X. Cao, W. J. Zhang, H. T. Lin, F. Zhou, L. F. Chen and S. H. Yu, Adv. Funct. Mater., 2011, 21, 3851-3858. DOI:10.1002/adfm.201100983

3. L. S. Zhong, J. S. Hu, H. P. Liang, A. M. Cao, W. G. Song and L. J. Wan, Adv. Mater., 2006, 18, 2426-2431. DOI:10.1002/adma.200600504

4. J. B. Zimmerman, J. R. Mihelcic, S. James, Environ. Sci. Technol., 2008, 42, 4247-4254. DOI:10.1021/es0871457

5. G. Crini, Bioresour. Technol., 2006, 97, 1061-1085. DOI:10.1016/j.biortech.2005.05.001

6. R. D. Ambashta and M. Sillanpää, J. Hazard. Mater., 2010, 180, 38-49. DOI:10.1016/j.jhazmat.2010.04.105

7. S. H. Chen, J. Zhang, C. L. Zhang, Q. Y. Yue, Y. Li and C. Li, Desalination, 2010, 252, 149-156.

DOI:10.1016/j.desal.2009.10.010

8. A. Mittal, A. Malviya, D. Kaur, J. Mittal and L. Kurup, J. Hazard. Mater. 2007, 148, 229-240.

DOI:10.1016/j.jhazmat.2007.02.028

9. S. B. Wang, Y. Boyjoo, A. Choueib and Z. H. Zhu, Water Res. 2005, 39, 129-138. DOI:10.1016/j.watres.2004.09.011

10. J. B. Zimmerman, J. R. Mihelcic and S. James, Environ. Sci. Technol. 2008, 42, 4247-4254. DOI:10.1021/es0871457

11. Z. Xiong, L. L. Zhang, J. Ma and X. S. Zhao, Chem. Commun., 2010, 46, 6099-6101. DOI:10.1039/c0cc01259a

12. S. Prakash, A. M. Rajesh and V. K. Shahi, Chem. Eng. J., 2011, 168, 108-114. DOI:10.1016/j.cej.2010.12.047

13. L. Ai, H. Yue and J. Jiang, Nanoscale, 2012, 4, 5401-5408. DOI:10.1039/C2NR31333B

14. B. Wang, H. Wu, L. Yu, R. Xu, T. T. Lim, and X. W. Lou, $A d v$. Mater., 2012, 24, 1111-1116.

DOI:10.1002/adma.201104599

15. J. C. Crittenden, R. R. Trussell, D. W. Hand, K. J. Howe and, G. Tchobanoglous, Water Treatment: Principles and Design, 2nd ed.; Wiley: Chichester, U.K., 2005.

16. Y. J. Xu, G. Weinberg, X. Liu, O. Timpe, R. Schlogl and D. S. 
Su, Adv. Funct. Mater., 2008, 18, 3613-3619.

DOI:10.1002/adfm.200800726

17. T. Zhu, J. S. Chen and X. W. Lou, J. Phys. Chem. C, 2012, 116, 6873-6878. DOI:10.1021/jp300224s

18. M. Valix, W. H. Cheung and G. Mckay, Langmuir, 2006, 22, 4574-4582. DOI:10.1021/la051711j

19. N. K. Lazaridis, G. Z. Kyzas, A. A. Vassiliou and D. N. Bikiaris, Langmuir, 2007, 23, 7634-7643. DOI:10.1021/la700423j

20. E. Alvarez-Ayuso, A. Garcia-Sanchez and X. Querol, Water Res., 2003, 37, 4855-4862. DOI:10.1016/j.watres.2003.08.009

21. M. S. Mauter, M. Elimelech, Environ. Sci. Technol. 2008, 42, 5843-585. DOI:10.1021/es8006904

22. M. Liu, C. Chen, J. Hu, X. Wu and X. Wang, J. Phys. Chem. C, 2011, 115, 25234-25240. DOI:10.1021/jp208575m

23. J. W. Zhang, J. H. Luo, P. M. Wang, B. Ding, Y. C. Huang, Z. L. Zhao, J. Zhang and Y. G. Wei, Inorg. Chem., 2015, 54, 2551-2559. DOI:10.1021/ic502622k

24. S. S. Wang and G. Y. Yang, Chem. Rev., 2015, 115, 4893-4962. DOI:10.1021/cr500390v

25. J. S. Li, X. J. Sang, W. L. Chen, L. C. Zhang, Z. M. Zhu, Y. G. Li, Z. M. Su and E. B. Wang, J. Mater. Chem. A, 2015, 3, 14573-14577. DOI:10.1039/C5TA03259H

26. U. Kortz, A. Muller, J. V. Slageren, J. Schnack, N. S. Dalal and M. Dressel, Coord. Chem. Rev., 2009, 253, 2315-2327.

DOI:10.1016/j.ccr.2009.01.014

27. J. T. Rhule, C. L. Hill, D. A. Judd and R. F. Schinazi, Chem. Rev., 1998, 98, 327-358. DOI:10.1021/cr960396q

28. A. X. Yan, S. Y, Y. G. Li, Z. M. Zhang, Y. Lu, W. L. Chen and E. B. Wang, Chem. Eur. J., 2014, 20, 6927-6933. DOI:10.1002/chem.201400175

29. V. K. Gupta, T. A. Saleh, Environ. Sci. Pollut. Res., 2013, 20, 2828-2843. DOI:10.1007/s11356-013-1524-1

30. Y. Chen, S. Zhao and Y. F. Song, Appl. Catal. A: Gen., 2013, 466, 307-314. DOI:10.1016/j.apcata.2013.06.030

31. A. Tayyebi and M. Outokesh, RSC Adv., 2016, 6, 13898-13913.

32. M. Yusuf, F. Elfghi, S. A. Zaidi, E. Abdullah and M. A. Khan, RSC Adv., 2015, 5, 50392-50420.

33. Z. H. Cheng, J. Liao, B. Z. He, F. Zhang, F. A. Zhang, X. H. Huang and L. Zhou, ACS Sustain. Chem. Eng. 2015, 3, 16771685. DOI:10.1021/acssuschemeng.5b00383

34. J. Li, C. L. Chen, R. Zhang and X. K. Wang, Sci. China Chem., 2016, 59, 150-158. DOI:10.1007/s11426-015-5452-4

35. G. X. Zhao, L. Jiang, Y. D. He, J. X. Li, H. L. Dong and X. K. Wang, W. P. Hu, Adv. Mater., 2011, 23, 3959-3963.

DOI:10.1002/adma.201101007

36. J. Wang, Z. M. Chen and B. L. Chen, Environ. Sci. Technol., 2014, 48, 4817-4825. DOI:10.1021/es405227u

37. H. Wang, X. Z. Yuan, G. M. Zeng, Y. Wu, Y. Liu, Q. Jiagn and S. S. Gu, Adv. Colloid Interface Sci., 2015, 221, 41-59. DOI:10.1016/j.cis.2015.04.005

38. H. Wang, X. Z. Yuan, Y. Wu, H. J. Huang, X. Peng, G. M. Zeng, H. Zhong, J. Liang and M. M. Ren, Adv. Colloid Interface Sci., 2013, 195-196, 19-40. DOI:10.1016/j.cis.2013.03.009

39. H. Wang, X. Z. Yuan, Y. Wu, H. J. Huang, G. M. Zeng, Y. Liu, X. L. Wang, N. B. Lin and Y. Qi, Appl. Surf. Sci., 2013, 279, 432-440. DOI:10.1016/j.apsusc.2013.04.133
40. H. Chen, B. Gao and H. Li, J. Hazard. Mater., 2015, 282, 201207. DOI:10.1016/j.jhazmat.2014.03.063

41. P. Wang, Q. Shi, Y. Shi, K. K. Clark, G. D. Stucky and A. A. Keller, J. Am. Chem. Soc., 2008, 131,182-188.

DOI:10.1021/ja806556a

42. S. Zhang, H. Li, Z. Wang, J. Liu, H. Zhang, B. Wang and Z. Yang, Nanoscale, 2015, 7, 8495-8502.

DOI:10.1039/C5NR00527B

43. X. J. Deng, L. L. Lü, H. W. Li and F. Luo, J. Harzard. Mater., 2010, 183, 923-930.

44. M. C. Liu, T. Wen, X. L. Wu, C. L. Chen, J. Hu, J. X. Li and X. K. Wang, Dalton Trans., 2013, 43, 14710-14717.

DOI:10.1039/c3dt50955a

45. J. Zhu, S. Wei, H. Gu, S. B. Rapole, Q. Wang, Z. Luo, N. Haldolaarachchige, D. P. Young and Z. Guo, Environ. Sci. Technol., 2012, 46, 977-98. DOI:10.1021/es2014133

46. Y. Liu, C. Luo, G. Cui and S. Yan, RSC Adv., 2015, 5, 5415654164.

47. X. Bai, R. Feng, Z. Hua, L. Zhou and H. Shi, Environ. Eng. Sci., 2015, 32, 370-378. DOI:10.1089/ees.2014.0015

48. F. Gu, M. Liang, D. Han and Z. Wang, RSC Adv., 2015, 5, 39964-39972.

49. Y. J. Yao, S. D. Miao, S. Z. Liu, L. P. Ma, H. Q. Sun and S. B. Wang, Chem. Eng. J., 2012, 184, 326-332.

DOI:10.1016/j.cej.2011.12.017

50. N. I. Kovtyukhova, P. J. Ollivier, B. R. Martin, T. E. Mallouk, S. A. Chizhik, E. V. Buzaneva and A. D. Gorchinskiy, Chem. Mater., 1999, 11, 771-778. DOI:10.1021/cm981085u

51. X. Gong, G. Liu, Y. Li, D. Y. W. Yu and W. Y. Teoh, Chem. Mater., 2016, 28, 8082-8118.

DOI:10.1021/acs.chemmater.6b01447

52. L. Zhao, Y. Chi, Q. Yuan, N. Li, W. Yan and X. Li, J. Colloid Interface Sci., 2013, 390, 70-77.

DOI:10.1016/j.jcis.2012.08.059

53. Z. Zhang, F. Zhang, Q. Zhu, W. Zhao, B. Ma and Y. Ding, J. Colloid Interface Sci., 2011, 360, 189-194.

DOI:10.1016/j.jcis.2011.04.045

54. M. Masteri-Farahania, J. Movassagh, F. Taghavi, P. Eghbali and F. Salimi, Chem. Eng. J., 2012, 184, 342-346.

DOI:10.1016/j.cej.2011.12.094

55. Y. Fu and X. Wang, Ind. Eng. Chem. Res., 2011, 50, 7210-7218. DOI:10.1021/ie200162a

56. G. H. Moon, Y. Park, W. Kim and W. Choi, Carbon, 2011, 49, 3454-3462. DOI:10.1016/j.carbon.2011.04.042

57. L. Q. Guo, P. R. Ye, J. Wang, F. F. Fu and Z. J. Wu, J. Hazard. Mater., 2015, 298, 28-35.

DOI:10.1016/j.jhazmat.2015.05.011

58. Q. S. Zhao, D. F. Chen, Y. Li, G. L. Zhang, F. B. Zhang and X. B. Fan, Nanoscale, 2013, 5, 882-885.

DOI:10.1039/C2NR33290F

59. M. A. Ghasemzadeh, B. Molaei, M. H. Abdollahi-Basir and F. Zamani, Acta Chim. Slov., 2017, 64, 73-82.

DOI:10.17344/acsi.2016.2823

60. S. K. Singh, M. K. Singh, P. P. Kulkarni, V. K. Sonkar, J. J. A. Gracio and D. Dash, ACS Nano, 2012, 6, 2731-2740. DOI:10.1021/nn300172t 
61. C. Rocchiccioli-Deltcheff, M. Fournier, R. Franck and R. Thouvenot, Inorg. Chem., 1983, 22, 207-216. DOI:10.1021/ic00144a006

62. H. Zhang, A. J. Xie, Y. H. Shen, L. G. Qiu and X. Y. Tian, Phys. Chem. Chem. Phys., 2012, 14, 12757-12763. DOI:10.1039/c2cp41561e

63. D. Zhou and B. H. Han, Adv. Funct. Mater., 2010, 20, 27172722. DOI:10.1002/adfm.200902323

64. Y. B. Sun, D. D. Shao, C. L. Chen, S. B. Yang and X. K. Wang, Environ. Sci. Technol. 2013, 47, 9904-9910.

DOI:10.1021/es401174n

65. Y. Sun, D. Shao, C. Chen, S. Yang and X. Wang, Environ. Sci. Technol., 2013, 47, 9904-9910. DOI:10.1021/es401174n

66. S. Alwarappan, A. Erdem, C. Liu and C.-Z. Li, J. Phys. Chem. C, 2009, 113, 8853-8857. DOI:10.1021/jp9010313

67. Y.-X. Ma, Y.-F. Li, G.-H. Zhao, L.-Q. Yang, J.-Z. Wang, X. Shan and X. Yan, Carbon, 2012, 50, 2976-2986.

DOI:10.1016/j.carbon.2012.02.080

68. L. M. Cui, Y. G. Wang, L. Gao, L. H. Hu, L. G. Yan, Q. Wei and B. Du, Chem. Eng. J., 2015, 281, 1-10. DOI:10.1016/j.cej.2015.06.043

69. W. Zhang, M. Wang, W. Zhao and B. Wang, Dalton Trans., 2013, 42, 15464-15474. DOI:10.1039/c3dt52068d

70. X. Q. Tian, C. M. Cheng, L. Qian, B. Z. Zheng, H. Y. Yuan, S. P. Xie, D. Xiao and M. M. F. Choi, J. Mater. Chem., 2012, 22, 8029-8035. DOI:10.1039/c2jm16057a

71. H. Pang, Y. H. Ma, G. C. Li, J. Chen, J. S. Zhang, H. H. Zheng and W. M. Du, Dalton Trans., 2012, 41, 13284-13291. DOI:10.1039/c2dt31916k

72. L. Li, X. L. Liu, H. Y. Geng, B. Hu, G. W. Song and Z. S. Xu, J. Mater. Chem. A, 2013, 1, 10292-10299.

DOI:10.1039/c3ta11478c

73. X. Zhao, X. Bu, T. Wu, S.-T. Zheng, L. Wang and P. Feng, Nat. Commun., 2013, 4, 1-9.

74. R. Li, X. Q. Ren, J. S. Zhao, X. Feng, X. Jiang, X. X. Fan, Z. G.
Lin, X. G. Li, C. G. Hu and B. Wang, J. Mater. Chem. A, 2014, 2, 2168-2173. DOI:10.1039/C3TA14267A

75. C. D. Woolard, J. Strong and C. R. Erasmus, Appl. Geochem., 2002, 17, 1159-1164. DOI:10.1016/S0883-2927(02)00057-4

76 Y. Yao, S. Miao, S. Liu, L. P. Ma, H. Sun and S. Wang, Chem. Eng. J., 2012, 184, 326-332. DOI:10.1016/j.cej.2011.12.017

77. C. Zou, Z. J. Zhang, X. Xu, Q. H. Gong, J. Li and C. D. Wu, J. Am. Chem. Soc., 2012, 134, 87-90.

DOI:10.1021/ja209196t

78 T. Liu, Y. Li, Q. Du, J. Sun, Y. Jiao, G. Yang, Z. Wang, Y. Xia, W. Zhang and K. Wang, Colloids Surf., B, 2012, 90, 197-203. DOI:10.1016/j.colsurfb.2011.10.019

79. A. A. Farghali, M. Bahgat, W. M. A. El Rouby and M. H. Khedr, J. Solution Chem. 2012, 41, 2209-2225.

DOI:10.1007/s10953-012-9934-0

80. X. X. Liu, W. P. Gong, J. Luo, C. T. Zou, Y. Yang and S. J. Yang, Appl. Surf. Sci., 2016, 362, 517-524.

DOI:10.1016/j.apsusc.2015.11.151

81. T. T. Zhu, Z.-M. Zhang, W.-L. Chen, Z.-J. Liu and E.-B. Wang, RSC Adv., 2016, 6, 81622-81630

82. A. X. Yan, S. Y, Y. G. Li, Z. M. Zhang, Y. Lu, W. L. Chen and E. B. Wang, Chem. Eur. J., 2014, 20, 6927-6933.

DOI:10.1002/chem.201400175

83. Y.-Q. Zhang, C.-C. Wang, T. Zhu, P. Wang and S.-J. Gao, RSC Adv. 2015, 5, 45688-45692.

84. L. Li, X. L. Liu, H. Y. Geng, B. Hu, G. W. Song and Z. S. Xu; J. Mater. Chem., A, 2013, 1, 10292-10299.

DOI: $10.1039 / \mathrm{c} 3 \operatorname{ta} 11478 \mathrm{c}$

85. Y. Yao, F. Xu, M. Chen, Z. Xu and Z. Zhu, Bioresour. Technol., 2010, 101, 3040-3046. DOI:10.1016/j.biortech.2009.12.042

86. E. Haque, J. W. Jun and S. H. Jhung, J. Hazard. Mater., 2011, 185, 507-511. DOI:10.1016/j.jhazmat.2010.09.035

87. Y. Li, Q. Du, T. Liu, J. Sun, Y. Wang, S. Wu, Z. Wang, Y. Xia and L. Xia, Carbohydr. Polym., 2013, 95, 501-507.

DOI:10.1016/j.carbpol.2013.01.094

\section{Povzetek}

$\mathrm{V}$ raziskavi poročamo o vezavi polianionov $\mathrm{PMo}_{12} \mathrm{O}_{40}{ }^{3-}$ na amino funkcionalizirane nanoplasti grafenovega oksida (GO). Tako pripravljen ternarni magnetni nanokompozit $\left(\mathrm{Fe}_{3} \mathrm{O}_{4} / \mathrm{GO}-\mathrm{NH}_{2} / \mathrm{H}_{3} \mathrm{PMo}_{12} \mathrm{O}_{40}\right)$ smo karakterizirali $\mathrm{z}$ naslednjimi metodami: rentgensko praškovno difrakcijo (XRD) infrardečo spektroskopijo (FTIR), ramansko spektroskopijo, energijsko disperzivno spektroskopijo (EDS), vrstično elektronsko mikroskopijo z emisijo polja (FE-SEM), meritvami površine (BET), magnetnimi meritvami (VSM) in mikroskopijo na atomsko silo (AFM). Rezultati so pokazali uspešno vezavo $\mathrm{H}_{3} \mathrm{PMo}_{12} \mathrm{O}_{40}$ (utežni delež $\sim 36.5 \%$ ) na površino magnetnega grefenovega oksida. Specifična površina nanokompozita je bila višja $\left(77.07 \mathrm{~m}^{2} / \mathrm{g}\right)$ od čistega $\mathrm{H}_{3} \mathrm{PwMo}_{12} \mathrm{O}_{40}\left(\leq 10 \mathrm{~m}^{2} / \mathrm{g}\right)$. Preučevali smo adsorpcijsko učinkovitost nanokompozita $\mathrm{v}$ primerih odstranjevanja nekaterih barvil (metilen modro, rodamin B in metiloranž) iz vodnih raztopin. Z uporabo nanokompozita smo prikazali hitro in selektivno adorpcijo za kationska barvila iz mešanih raztopin barvil. Stopnja in kapaciteta adsorpcije $\mathrm{Fe}_{3} \mathrm{O}_{4} / \mathrm{GO}-\mathrm{NH}_{2} / \mathrm{H}_{3} \mathrm{PMo}_{12} \mathrm{O}_{40}$ sta bili povečani v primerjavi z GO, GO- $\mathrm{NH}_{2}, \mathrm{Fe}_{3} \mathrm{O}_{4} / \mathrm{GO}_{-} \mathrm{NH}_{2}$ in $\mathrm{H}_{3} \mathrm{P}-$ $\mathrm{Mo}_{12} \mathrm{O}_{40}$ zaradi povečane elektrostatske privlačnosti in interakcij preko vodikovih vezi. Nanokompozit lahko ločimo $\mathrm{z}$ magneti in ponovno uporabimo, pri čemer v kompozitu ne pride do strukturnih sprememb. Menimo, da nanokompozit $\mathrm{Fe}_{3} \mathrm{O}_{4} / \mathrm{GO}-\mathrm{NH}_{2} / \mathrm{H}_{3} \mathrm{PMo}_{12} \mathrm{O}_{40}$ predstavlja obetaven “zeleni” adsorbent za odstranjevanje organskih onesnaževal iz voda. 